\title{
A LARGER ROOT SYSTEM IN OAT (AVENA NUDA L.) IS COUPLED WITH ENHANCED BIOMASS ACCUMULATION AND HORMONAL ALTERATIONS UNDER LOW NITROGEN
}

\author{
KHAN, T. A. ${ }^{1}-$ NADEEM, F. ${ }^{2}-$ GAO, Y. ${ }^{1}-$ YANG, Y. ${ }^{1}-$ WANG, X. ${ }^{1}-$ ZENG, Z. ${ }^{1}-$ HU, Y.${ }^{1 *}$ \\ ${ }^{1}$ College of Agronomy, China Agricultural University, 100193 Beijing, China \\ ${ }^{2}$ College of Resources and Environmental Sciences, China Agricultural University, \\ 100193 Beijing, China \\ *Corresponding author \\ e-mail: huyuegao@gmail.com, huyuegao@cau.edu.cn; phone: +86-10-6273-2441; fax: +86- \\ 10-6273-2441
}

(Received $8^{\text {th }}$ Jan 2019; accepted $14^{\text {th }}$ Feb 2019)

\begin{abstract}
Nitrogen (N), an essential macronutrient for crop growth and development, is well known for its economic losses and environmental hazards due to imbalanced application. Oat (Avena nuda L.), a food and fodder crop, is well adapted to marginal soils and requires minimum water and nutrients to produce biomass. A hydroponic experiment was conducted in China Agricultural University, Beijing, China to evaluate the morphological and physiological adaptations of oat to organic $\mathrm{N}(\mathrm{ON})$ and low $\mathrm{N}$ (LN) with respect to chemical $\mathrm{N}$ (CK as control). The results have shown that oat responded to different nitrogen supplies with response to $\mathrm{LN}$ having been the dominant one. Lowest SPAD value, net photosynthesis rate, transpiration rate, gas exchange and stomatal conductance showed that the oat was under LN stress. Highest level of root dry mass, as indicated by increased R/S ratio and $\mathrm{C} / \mathrm{N}$ ratio, was at the cost of minimum nitrogen utility as depicted by increased nitrogen utilization efficiency in roots under LN. Accumulation of total soluble proteins and sugars elaborated the carbon allocation to nitrogen deprived roots. As a result of sufficient biomass provision in LN root, total root length increased which was coupled with increased concentrations of indole-3-acetic acid, gibberellic acid and zeatin riboside whereas decreased concentration of abscisic acid. Overall, oat is found to be a nitrogen use efficient crop which responded to LN through enhanced root system through biomass accumulation by the provision of nitrogen metabolites.
\end{abstract}

Keywords: root architecture, photosynthesis, nitrogen utilization efficiency (NUtE), nitrogen metabolites, hormonal accumulation

\section{Introduction}

Nitrogen (N) is an important macronutrient required for the biosynthesis of chlorophyll, nucleic acids, amino acids, proteins and some organic acids. Its essentiality is obvious from its involvement in most of the biological and physiological processes such as photosynthesis, biomass production, hormonal accumulation, carbohydrate allocation, plant root architectural growth and development of reproductive organs of plants (Zhao et al., 2005; Miller and Cramer, 2005). To produce $1 \mathrm{~kg}$ biomass most of the non-legume plants absorb 20 to $50 \mathrm{~g}$ of $\mathrm{N}$ from the soil (Robertson and Vitousek, 2009). Nitrogen is present in soils in a patchy manner either as inorganic form (nitrate or ammonium) or organic form (amino acids, peptides and proteins). Plants uptake different nitrogen forms from the soil through roots with nitrate being the most preferential form (Yuan et al., 2007; Puangfoo-Lonhienne et al., 2008 and Wang et al., 2012). Being highly mobile element, nitrogen is subjected to losses once applied to the soil as inorganic form whereas nitrogen released by organic forms is slow which cannot meet the plant requirement. 
Hence, farmers are compelled to use chemical nitrogen fertilizers which, more often than not, which damages soil physical and chemical health, and toxifies the environment. Approximately $10^{11} \mathrm{~kg} \mathrm{~N}$ per annum is applied in the soil globally with the aim to get highest crop production (Glass, 2003; Tilman et al., 2011; Liu et al., 2013; Chandna et al., 2011; Rawat et al., 2012). Hence, high levels of soil N are susceptible to losses (Zhu et al., 2002; Ju et al., 2004) which ultimately can reduce the $\mathrm{N}$ use efficiency (NUE) (AtaUl-Karim et al., 2014). On the other hand, deficiency of $\mathrm{N}$ reduces the biosynthesis of chlorophyll, affects plant organ development and finally results in reduced crop yield (Marschner, 1995). Plants have developed morphological and physiological alterations over evolution to cope with heterogeneous environmental conditions. Nitrogen is present in soil solution in mineral as well as organic form (Nasholm and Persson, 2001); thus, it depends on the adaptability of a plant to dwell under the conditions of its high or low availability (Glass, 2003; Garnett et al., 2009). The primary response of a plant to low external nitrogen availability is to modify its root system. Most plants expand their root system to capture $\mathrm{N}$ by exploring as much rhizosphere as possible (Palta, et al., 2011). Leguminous crops form root nodules to fix atmospheric $\mathrm{N}$ but non-leguminous crops like maize, rice produce longer roots (Wang et al., 2003; Chun et al., 2005a) whereas, foxtail millet produces shorter and thicker roots facilitating carbohydrate allocation perhaps through wider xylem vessels (Nadeem et al., 2018). Hence, the diversity is observed in the adaptive measures of different crops under different rhizosphere condition.

Naked oat (Avena nuda L.) and hulled oat (A. sativa L) are two types of oats cultivated in China. The fast growing nature of oat capacitates itself to produce ample quantity of fresh fodder within short period of time with high nutritional values. The high protein and $\beta$-glucone content along with the presence of hypo-glycemic fiber content in oat grain increase its value as a human food. Generally, rice, wheat, maize and other high yielding cereal crops generally occupy most of the agricultural land but crops like oat find very limited area and interest to be cultivated worldwide. Current study was aimed to characterize root morphological and physiological adaptations of oat in order to maximize its nitrogen utilization efficiency (NUtE) in terms of biomass accumulation under different nitrogen supplies. The findings revealed oat as an extremely large root crop under low nitrogen (LN) condition with remarkable nitrogen use efficiency and biomass accumulation.

\section{Materials and methods}

The hydroponic experiment was carried out during April-July in a standard growth chamber with $28 / 22{ }^{\circ} \mathrm{C}$ alternate day night temperature, $14 / 10 \mathrm{~h}$ (day/night) photoperiod, $65 \%$ relative humidity and $300 \mu \mathrm{mol}$ photons $\mathrm{m}^{-2} \mathrm{~s}^{-1}$ illumination in China Agricultural University, Beijing, China. High quality seeds of oat (Avena nuda L.) variety Baiyan 2 were collected from Baicheng Academy of Agricultural Science, Jilin, China. Deionized $\mathrm{H}_{2} \mathrm{O}$ was used to wash the seeds followed by sterilization with $10 \% \mathrm{H}_{2} \mathrm{O}_{2}$ solution for 30 min and soaking in saturated $\mathrm{CaSO}_{4}$ solution for $5 \mathrm{~h}$ with continuous aeration. Seeds were germinated on moist tray in the growth chamber. After emergence of approximately $2 \mathrm{~cm}$ primary roots, seedlings were wrapped with two layers of deionized water saturated filter paper, enfolded in cylinder shape and placed vertically in a growth holder containing distilled water to assure a continuous water supply to the seedlings. 12 uniform and consistent seedlings with two fully emerged leaves were selected and transplanted into well aerated 5-L vessels containing nutrient solution. The total nutrient solution (as 
control or CK) consisted of $2 \mathrm{mM} \mathrm{NH}_{4} \mathrm{NO}_{3}, 0.75 \mathrm{mM} \mathrm{K}_{2} \mathrm{SO}_{4}, 0.25 \mathrm{mM} \mathrm{KH}_{2} \mathrm{PO}_{4}, 0.1 \mathrm{mM}$ $\mathrm{KCl}, 0.2 \mathrm{mM}$ Fe-EDTA, $0.65 \mathrm{mM} \mathrm{MgSO}_{4}, 2 \mathrm{mM} \mathrm{CaCl}_{2}, 1 \times 10^{-3} \mathrm{mM} \mathrm{ZnSO}_{4}, 1 \times 10^{-3}$ $\mathrm{mM}$ MnSO4, $5 \times 10^{-6} \mathrm{mM}\left(\mathrm{NH}_{4}\right)_{6} \mathrm{Mo}_{7} \mathrm{O}_{24}, 1 \times 10^{-4} \mathrm{mM} \mathrm{CuSO}_{4}$, and $1 \times 10^{-3} \mathrm{mM}$ $\mathrm{H}_{3} \mathrm{BO}_{3} .2 \mathrm{mM} \mathrm{NH} \mathrm{NO}_{3}$ was replaced by $4 \mathrm{mM}$ glycine $\left(\mathrm{C}_{2} \mathrm{H}_{5} \mathrm{NO}_{2}\right)$ as a source of organic nitrogen $(\mathrm{ON})$. Low nitrogen ( $\mathrm{LN})$ treatment contained $10 \%$ of $2 \mathrm{mM} \mathrm{NH} \mathrm{NOO}_{3}$ used in control (CK). Every treatment had six replicates. Each container had 12 plants. Oat seedlings were grown in nutrient solution for 21 days in total having $25 \%$ of CK solution for 3 days, $50 \%$ of CK solution for 4 days, $100 \%$ of CK solution for 7 days followed by the treatment application (CK, $\mathrm{ON}$ and $\mathrm{LN})$ for 7 days. The $\mathrm{pH}$ of the nutrient solution was adjusted to 5.8-6 and the nutrient solution was changed every 2 days. The whole experiment was repeated three times.

Plant roots and shoots were harvested, frozen in liquid $\mathrm{N}$ and stored in $-80{ }^{\circ} \mathrm{C}$ for amino acids, soluble proteins, soluble sugars and hormone analysis. Root samples were, washed with deionized water 3 times, surfaced dried using a blotting paper prior to storage. For other physiological analysis, shoot and root samples were harvested and dried in an oven at $105^{\circ} \mathrm{C}$ for $30 \mathrm{~min}$ and then at $70{ }^{\circ} \mathrm{C}$ until constant weight.

\section{Gas exchange and SPAD values (Soil and plant analyzer developer) measurements}

On the morning of $21^{\text {st }}$ day, between 8.00 to $9.00 \mathrm{am}$, the $3^{\text {rd }}$ fully expanded leaf of every plant of every replicate was measured in three points carefully with the help of a portable chlorophyll meter (SPAD-502, Minolta, Japan). Every pot had 12 seedlings. The three SPAD reads of every seedling were averaged to get 12 SPAD reads from every pot which served as technical replicates. On the same day a portable gas exchange system (LI-6400, LI-COR Biosciences, Lincoln, NE, USA) was used to measure photosynthetic rate $(\mathrm{Pn})$, gas exchange $(\mathrm{Ci})$, stomatal conductance (gs) and transpiration rate (Tr). Measurements were taken on $6 \mathrm{~cm}^{2}$ leaf area segment next to the mid-rib of the 4th leaf. Readings from 12 seedlings per pot served as 12 technical replicates and 6 pots of every treatment served as 6 biological replicates. Photosynthetic photon flux density provided by a red/blue LED light source (6400-02B, LI-COR Biosciences, Lincoln, NE, USA) was fixed to $600 \mu \mathrm{mol} \mathrm{m} \mathrm{m}^{-2} \mathrm{~s}^{-1}$ and the concentration of ambient $\mathrm{CO}_{2}$ was adjusted to $400 \mu \mathrm{mol}$ $\mathrm{mol}^{-1}$ by $\mathrm{CO}_{2}$ injection as reported by Geilfus et al. (2011).

\section{Root length analysis}

The root system was separated into crown and lateral roots. Each kind of roots was counted manually and crown roots were measured with a ruler. Roots were scanned using a scanner (Epson 1680, Indonesia). WinRHIZO software (version 5.0) (Regent Instruments Inc., Quebec City, QC, Canada) was used to analyze the scanned images to get total root length and average diameter following previously described methods (Peng et al., 2010). Lateral root length was obtained by subtracting crown root length from total root length. Lateral root density was defined as the number of lateral roots per unit length of crown root containing lateral roots. Each sample had three technical and six biological replicates.

\section{$N$ concentration analysis in the shoot and root}

The dried plant samples were weighed and ground into fine powder. $0.3 \mathrm{~g}$ of ground sample was taken for digestion by $\mathrm{H}_{2} \mathrm{SO}_{4}-\mathrm{H}_{2} \mathrm{O}_{2}$ followed by total $\mathrm{N}$ analysis using a modified Kjeldahl digestion method (Baker and Thompson, 1992). 


\section{Analysis of mineral concentration}

For the analysis of mineral contents of the plant using inductively coupled plasmamass spectrometry (ICP-MS; Agilent Technologies 7700 Series, Böblingen, Germany), the dried $\left(60^{\circ} \mathrm{C}\right)$ plant tissues were ground into fine powder. $100 \mathrm{mg}$ of fine powder was digested with $10 \mathrm{~mL}$ of $69 \% \mathrm{HNO}_{3}$ (ROTIPURAN Supra for ICP, 69\%) in an $1800 \mathrm{~W}$ microwave oven (MARS 6 Xpress; CEM, Matthews, MC, USA) at $100{ }^{\circ} \mathrm{C}$ for $2 \mathrm{~min}$, at $120{ }^{\circ} \mathrm{C}$ for $1 \mathrm{~min}$ and at $180{ }^{\circ} \mathrm{C}$ for $20 \mathrm{~min}$ followed by $20 \mathrm{~min}$ of cooling. Samples were diluted to $100 \mathrm{~mL}$ using sterilized deionized water $(18.2 \mathrm{M} \Omega \mathrm{cm}$ conductivity) and stored at $4{ }^{\circ} \mathrm{C}$ till analysis. Similar procedure also followed for blank digestions. A certified reference material NCSDC 73350 from the Beijing vegetable research institute (Beijing, China) was used for standardized analytical technique. Internal macro- and micronutrient standards and reference material samples were tested as internal control.

\section{Hormone extraction and quantification by enzyme linked immunosorbent assay (ELISA)}

Approximately $0.5 \mathrm{~g}$ fresh plant sample was ground into powder and homogenized by using $2 \mathrm{~mL}$ of $80 \%$ methanol (containing $40 \mathrm{mg} \mathrm{l}^{-1}$ butylated hydroxytoluene as an antioxidant), incubated $48 \mathrm{~h}$ at $4{ }^{\circ} \mathrm{C}$, and then centrifuged at $1900 \times \mathrm{g}$ for $15 \mathrm{~min}$ at $4{ }^{\circ} \mathrm{C}$. The supernatant was passed through C18 Sep-Pak cartridges (Waters Corp.), and the hormone fraction was eluted with $10 \mathrm{~mL}$ of $100 \%(\mathrm{v} / \mathrm{v})$ methanol and then $10 \mathrm{~mL}$ ether. The elute was $\mathrm{N}_{2}$-dried at $20{ }^{\circ} \mathrm{C}$. The $\mathrm{N}_{2}$ dried extracts were dissolved in $2.0 \mathrm{~mL}$ phosphate-buffered saline (PBS) containing $0.1 \%(\mathrm{v} / \mathrm{v})$ Tween-20 and $0.1 \%(\mathrm{w} / \mathrm{v})$ gelatin ( $\mathrm{pH}$ 7.5) to analyze the concentration of free indole-3-acetic acid (IAA), abscisic acid (ABA), gibberellic acid (GA) and zeatin riboside (ZR) by enzyme linked immunosorbent assay (ELISA) following a well-established protocol (Weiler et al., 1981).

\section{Extraction of metabolite and analyses}

The soluble proteins were extracted and analyzed by using a standard kit (Coomassie Protein assay reagent; Bio-Rad, Hercules, CA, USA) with bovine serum albumin as a reference. Chlorophyll was extracted from $0.2 \mathrm{~g}$ fresh leaf disks using $25 \mathrm{~mL}$ mixture of alcohol and acetone $(1: 1 \mathrm{v} / \mathrm{v})$. The absorbance of the extract was measured at 663, 645, and $470 \mathrm{~nm}$ using a UV-VIS spectrophotometer (UV-2600, Shimadzu, Japan) to estimate chlorophyll $\mathrm{a}$, chlorophyll $\mathrm{b}$ and total carotenoids according to the previously described methods Wellburn and Lichtenthaler (1984). The concentration of total free amino acids was measured according to the Rosen ninhydrin colorimetric method using leucine as a standard (Rosen, 1957). The concentration of soluble sugars was determined using a commercially available kit (Boehringer Mannheim, Germany). Individual amino acids profile was analyzed using Waters e2695 HPLC (Waters Corp, Milford, MA, USA) by incubating $100 \mathrm{mg}$ of fresh tissue powder with $1.5 \mathrm{~mL}$ of the $5 \%(\mathrm{w} / \mathrm{v})$ Trichloroacetic acid (TCA) solution for $1 \mathrm{~h}$ at room temperature. $\sim 50 \mathrm{mg}$ plant tissues were loaded into an Elementar vario Macro CN (Elementar Technologies, Hanau, Germany) analyzer for the $\mathrm{C}: \mathrm{N}$ ratio analysis.

\section{Statistical analysis}

Statistical analysis was performed using a windows software package (IBM SPSS Statistics 22). Means of different treatments were compared using the least significant 
difference at a 0.05 or 0.01 level of probability. Correlation analysis was performed using Pearson correlation function of SPSS. Graphical rendering was carried out using sigma plot 13.0 windows software. All the data were presented as means \pm standard errors (SE) of six replicates.

\section{Results}

\section{Root and shoot morphology of oat and biomass accumulation}

Oat seedlings were subjected to control $(\mathrm{CK})$, organic nitrogen $(\mathrm{ON})$ and low nitrogen (LN) treatments for one weak. At harvest, the seedlings showed obvious symptoms of various nitrogen regimes having green, mild green and light green (yellowish) shoot color in $\mathrm{CK}, \mathrm{ON}$ and $\mathrm{LN}$ respectively (Fig. 1A, B).
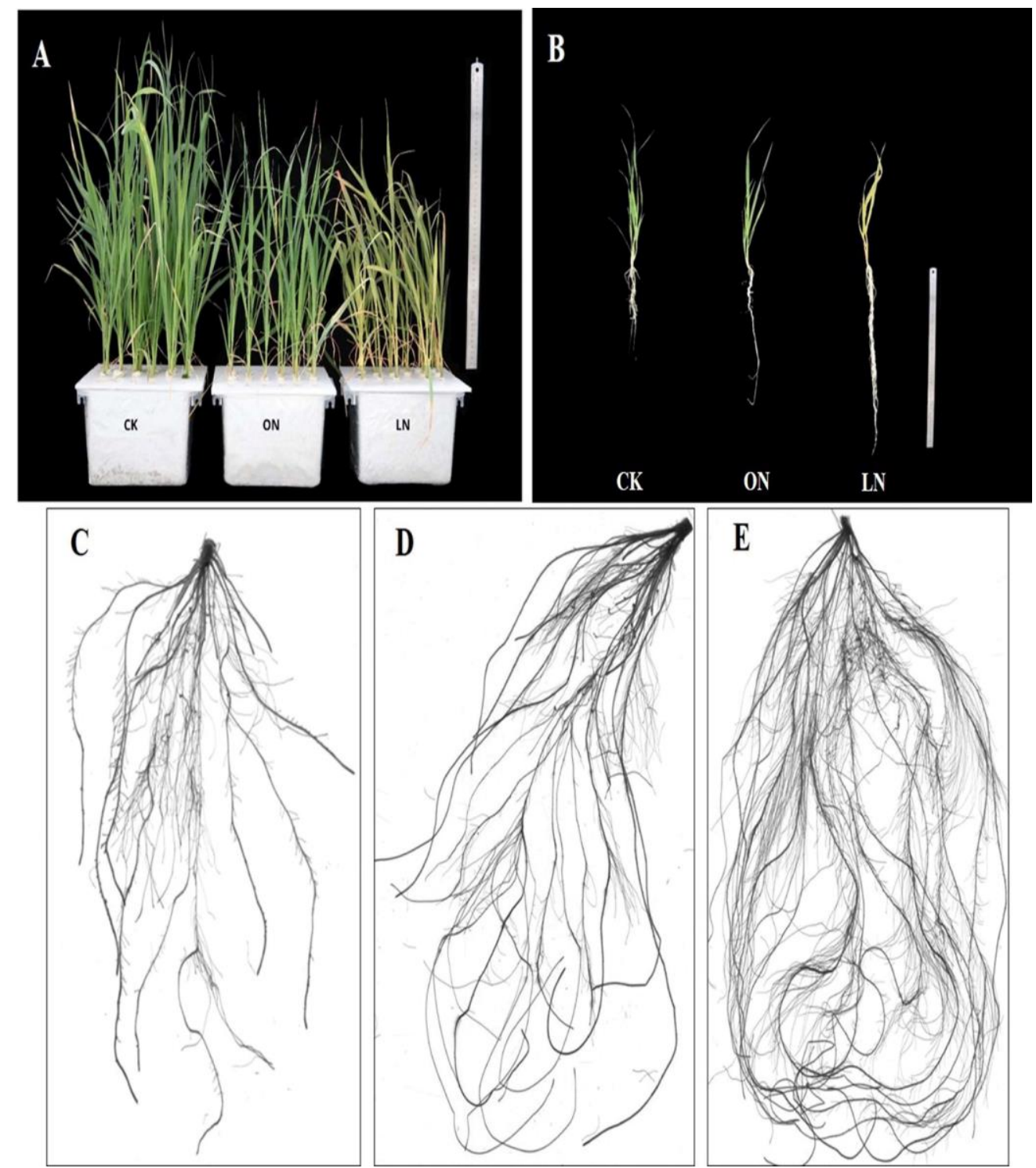

Figure 1. Shoot and root responses of oat to different form and level of $N$. Plants grown under $C K, O N$ and $L N$ condition in hydroponic pots $(A)$, plants with the intact root and shoot $(B)$, The whole scan picture of root under $C k(C), O N(D)$ and $L N(E)$. Treatment $C K=$ control, $O N=$ organic $N, L N=$ low $N$ 
During the harvesting time, each seedling under LN condition revealed the deficiency symptoms of $\mathrm{N}$. Limitation of $\mathrm{N}$ generally hinders oat plant growth. In current study, shoot length, leaf area and shoot dry weight decreased whereas root dry weight and root to shoot ratio increased in $\mathrm{ON}$ and $\mathrm{LN}$ treatments (Fig. 2A-E). Reduction in plant height was observed in the $\mathrm{ON}$ and $\mathrm{LN}$ treatment which was almost $14 \%$ and $28 \%$, respectively, in comparison with CK (Table Al in the Appendix). Compared to $\mathrm{CK}$ and ON treatment $45.77 \%$ and $35.77 \%$ less shoot dry weight and $82.61 \%$ and $31.25 \%$ higher root DW was produced under LN condition, respectively, (Table A2). Interestingly, root to shoot ratio resulted in $241.27 \%$ and $109.76 \%$ increment in $\mathrm{LN}$ treatment with respect to $\mathrm{CK}$ and $\mathrm{ON}$ respectively. Similar was the case in $\mathrm{ON}$ treatment where $62.7 \%$ increase in root to shoot ratio was observed as compared to $\mathrm{CK}$ (Table A2). Talking about root architectural traits (Fig. 1C-E), LN treatment increased total root length $(112.3 \%$ and $64.65 \%)$, crown root length $(116.27 \%$ and $75.91 \%)$, lateral root length $(111.57 \%$ and $63.46 \%)$, crown root number $(96.67 \%$ and $40.47 \%)$, and lateral root number $(34.1 \%$ and $16.39 \%)$ and density (128.21\% and 67.92\%) with respect to CK and ON whereas, ON treatment only increased lateral root number $(15.22 \%)$ and length $(29.43 \%)$ and total root length (28.78\%) significantly as compared to CK (Table 1; Table A3 and A4). Average diameter of roots decreased in LN significantly (Table 1).
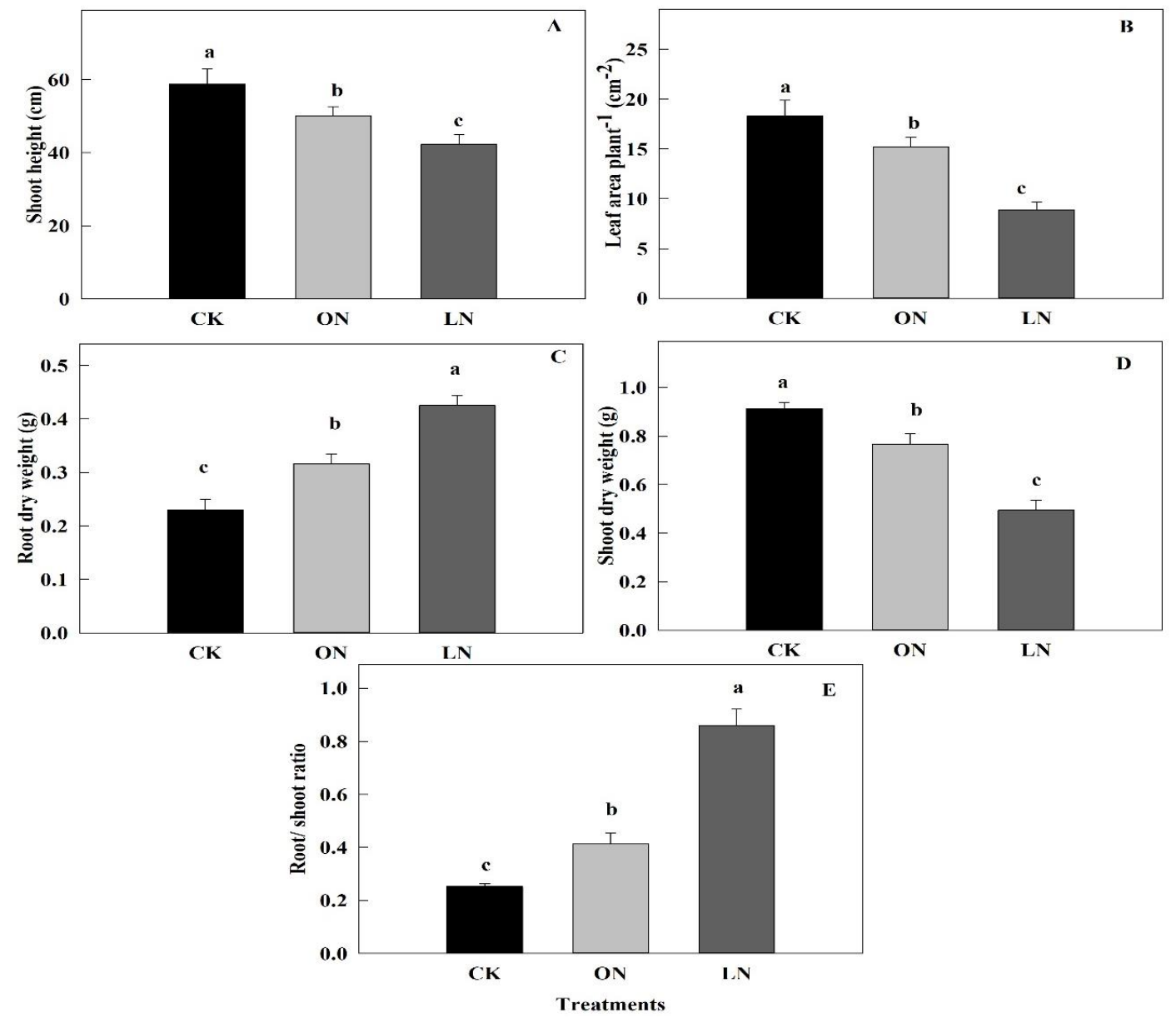

Figure 2. The oat plant responses to different form and level of $N$. Shoot height (A), leaf area plant $^{-1}(B)$, root dry weight $(C)$, shoot dry weight $(D)$ and root/shoot ratio $(E)$. Error bars represented standard error of six biological replicates, different letters indicate significant differences $(P<0.05)$. Treatment $C K=$ control, $O N=$ organic $N, L N=$ low $N$ 
Table 1. Root morphological characteristics under $C K, O N$ and $L N$ condition during harvesting

\begin{tabular}{c|c|c|c|c|c|c|c}
\hline Treatment & $\begin{array}{c}\text { Crown root } \\
\text { number }\end{array}$ & $\begin{array}{c}\text { Lateral root } \\
\text { number }\end{array}$ & $\begin{array}{c}\text { Lateral root } \\
\text { density }\end{array}$ & $\begin{array}{c}\text { Crown root } \\
\text { length }(\mathbf{c m})\end{array}$ & $\begin{array}{c}\text { Lateral root } \\
\text { length }(\mathbf{c m})\end{array}$ & $\begin{array}{c}\text { Total root length } \\
(\mathbf{c m})\end{array}$ & $\begin{array}{c}\text { Average } \\
\text { diameter }(\mathbf{c m})\end{array}$ \\
\hline $\mathbf{C K}$ & $7.5 \pm 0.87 \mathrm{~b}$ & $1736.17 \pm 15.2 \mathrm{c}$ & $7.8 \pm 0.98 \mathrm{~b}$ & $143.34 \pm 10.56 \mathrm{~b}$ & $1288.16 \pm 82.2 \mathrm{c}$ & $1431.5 \pm 97.36 \mathrm{c}$ & $0.073 \pm 0.0039 \mathrm{a}$ \\
$\mathbf{O N}$ & $10.5 \pm 1.08 \mathrm{~b}$ & $2000.4 \pm 123.3 \mathrm{~b}$ & $10.6 \pm 1.76 \mathrm{~b}$ & $176.23 \pm 13.98 \mathrm{~b}$ & $1667.22 \pm 102.1 \mathrm{~b}$ & $1843.45 \pm 131.23 \mathrm{~b}$ & $0.078 \pm 0.27 \mathrm{a}$ \\
$\mathbf{L N}$ & $14.75 \pm 2.22 \mathrm{a}$ & $2328.17 \pm 155.8 \mathrm{a}$ & $17.8 \pm 2.01 \mathrm{a}$ & $310 \pm 17.76 \mathrm{a}$ & $2725.3 \pm 178.3 \mathrm{a}$ & $3035.33 \pm 198.3 \mathrm{a}$ & $0.052 \pm 0.45 \mathrm{~b}$ \\
\hline
\end{tabular}

In each column lower case lettering is used to show the significant differences between different types of treatments at $\mathrm{P}<0.05$ level. Values show Standard errors (SE) \pm mean of four replicates. $\mathrm{CK}=100 \%$ chemical $\mathrm{N}, \mathrm{ON}=100 \%$ organic $\mathrm{N}$ and $\mathrm{LN}=\mathrm{Low} \mathrm{N}$

\section{Attributes of photosynthesis and nitrogen accumulation}

We found a continuous and significant decrease in SPAD value, Chlorophyll a, b and total carotenoids from CK to LN (Fig. 3A-D; Table A5). Moreover, net photosynthesis $(\mathrm{Pn})$, intercellular carbon dioxide $(\mathrm{Ci})$, transpiration rate $(\mathrm{Tr})$ and stomatal conductance $\left(\mathrm{g}_{\mathrm{s}}\right)$ followed the same pattern across all three treatments (Fig. 4A-D). Shoot and root nitrogen concentrations were decreased in the order of $\mathrm{CK}>\mathrm{ON}>\mathrm{LN}$ (Fig. 5A, B; Table $A 6)$, and vice versa for whereas for carbon to nitrogen $(\mathrm{C} / \mathrm{N})$ ratio and nitrogen utilization efficiency (cumulative biomass per unit of nitrogen; $\mathrm{g} \mathrm{DW} \mathrm{g}{ }^{-1} \mathrm{~N}$ in the plant; NUtE) in both shoot and root (Fig. 5C-F).
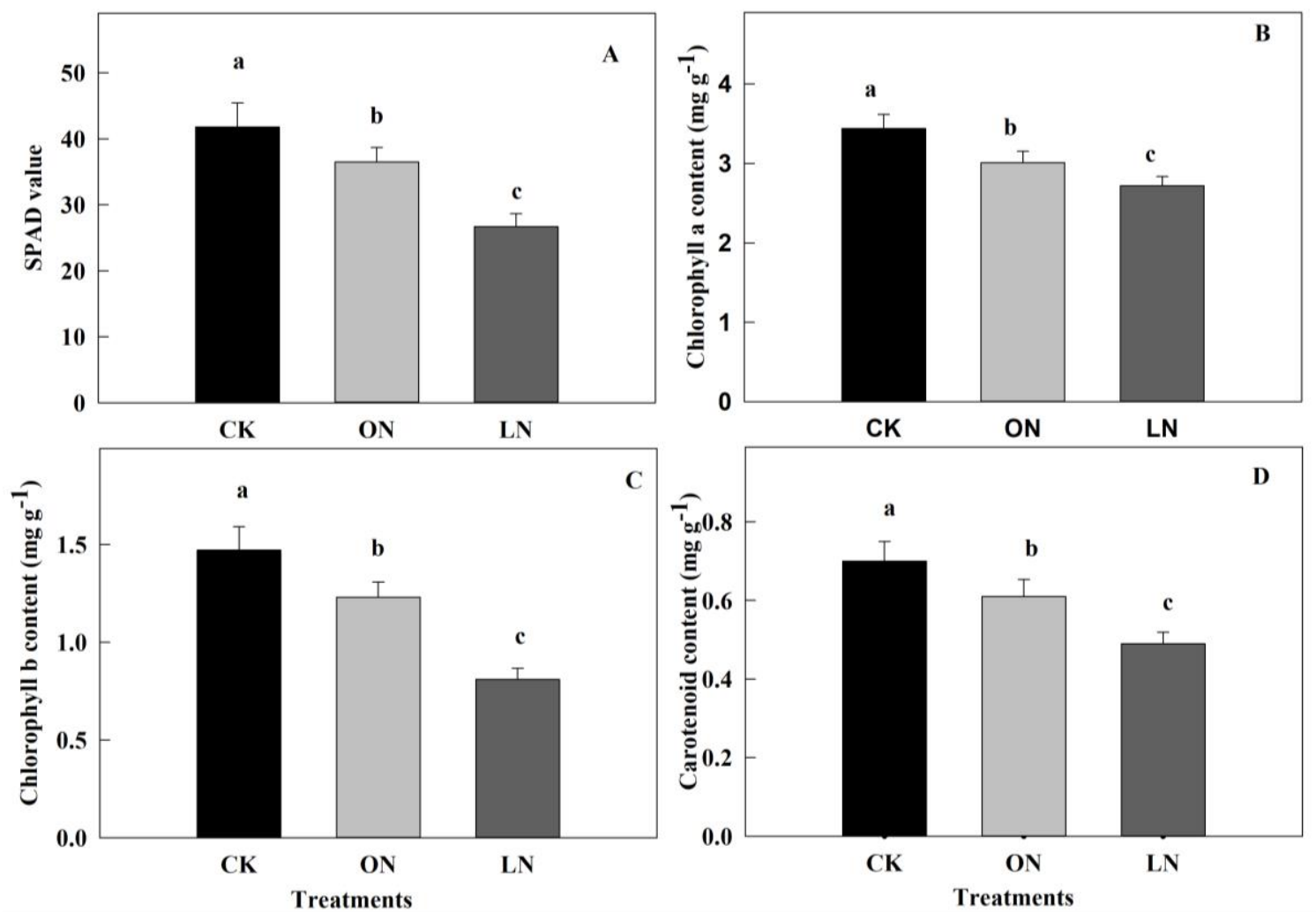

Figure 3. Comparison in chlorophyll contents of oat leaf grown under different sources and doses of N. SPAD value (A), chlorophyll a content $(B)$, chlorophyll b content $(C)$, carotenoid content (D). Error bars represented standard error of six biological replicates, different letters indicate significant differences $(P<0.05)$. Treatment $C K=$ control, $O N=$ organic $N, L N=$ low $N$ 

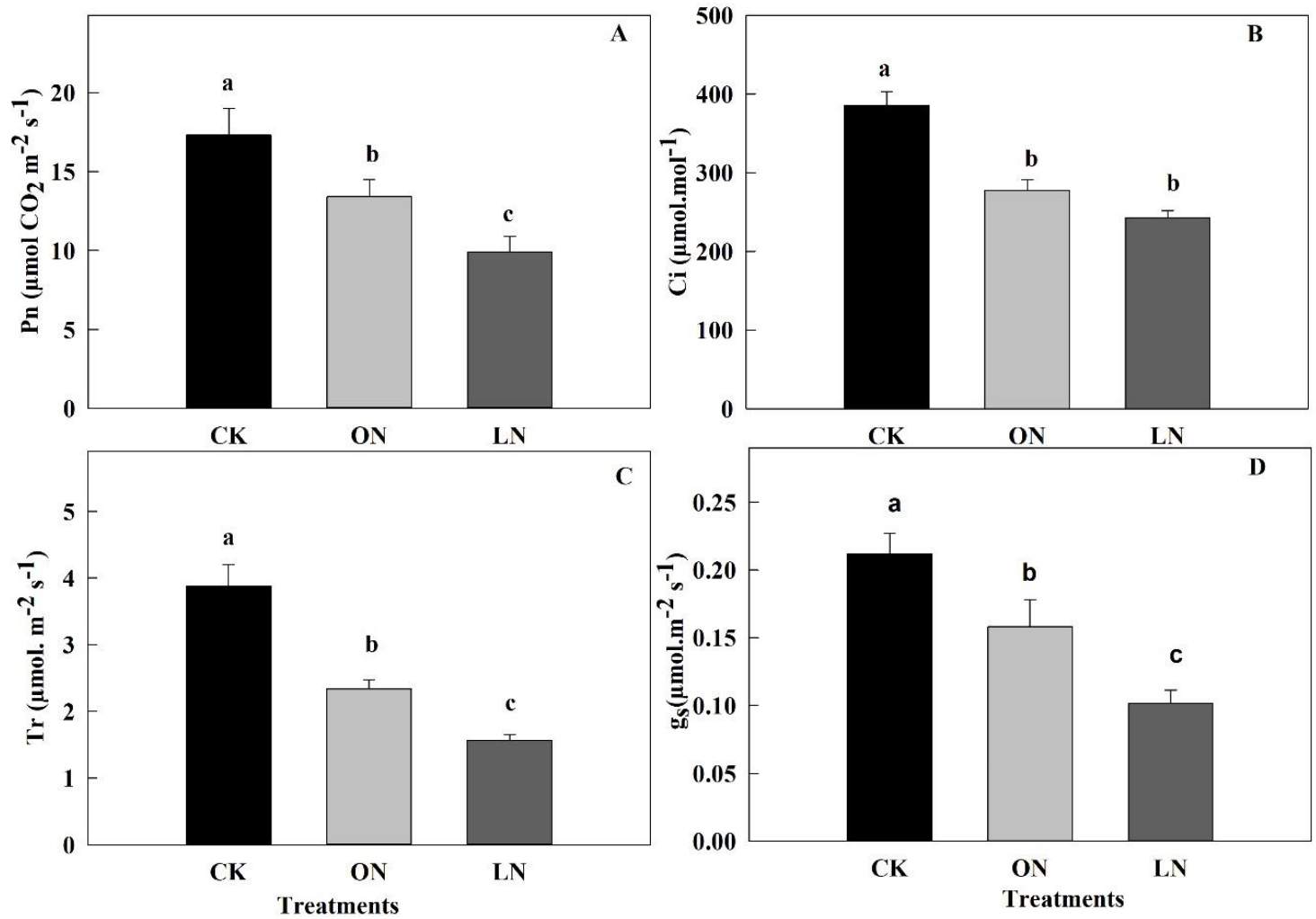

Figure 4. Trend of photosynthetic parameters in oat leaf under different treatment. Net photosynthetic rate $\mathrm{Pn}(\mathrm{A})$, inter cellular $\mathrm{CO} 2, \mathrm{Ci}(\mathrm{B})$, transpiration rate, $\mathrm{Tr}(\mathrm{C})$, stomatal conductance, $g_{s}(D)$ in response to $N$ treatments. Error bars represented standard error of six biological replicates, different letters indicate significant differences $(P<0.05)$. Treatment $C K=$ control, $O N=$ organic $N, L N=$ low $N$

\section{Free amino acids, total soluble proteins, total soluble sugars, amino acid profile and mineral status of oat}

Low nitrogen treatment reduced total free amino acids $(-26.78 \%$ and $-18.97 \%)$ in shoot as well as root $(-36.03 \%$ and $-25.76 \%)$ with respect to $\mathrm{CK}$ and $\mathrm{ON}$ however, no significance was found between $\mathrm{CK}$ and $\mathrm{ON}$ (Fig. 6A, B; Table A7). Total soluble proteins and sugars in shoot of oat decreased significantly $(\mathrm{CK}>\mathrm{ON}>\mathrm{LN})$ and vice versa in roots without any significance between $\mathrm{CK}$ and $\mathrm{ON}$ (Fig. 6C-F). Total soluble protein synthesis in shoot was found to be the least under LN treatment having decrements of $-73.42 \%$ and $-48.78 \%$ from CK and ON respectively, however, in roots they were increased up to $195 \%$ and $99.71 \%$ from CK and ON respectively under LN treatment (Table A7). Similarly, total soluble sugars in shoot of oat seedling were found to be minimal $(-57.73 \%$ and $-33.87 \%)$ whereas highest in roots $(159.68 \%$ and $80.9 \%)$ under $\mathrm{LN}$ treatment with respect to $\mathrm{CK}$ and $\mathrm{ON}$ (Table A7). In current study amino acids profile of shoot and root of oat seedlings under CK, ON and LN treatments was generated and found that 18 amino acids (Glu, ser, Gln, Ala, $\beta$-Ala, Val, Asp, Asn, Lys, Ile, Gly, Tyr, Trp, His, Leu, Orn, Cit, Tau) in shoot and 15 amino acids (Glu, Ser, Gln, Arg, Ala, $\beta$-Ala, Asp, Lys, Gly, Tyr, Leu, Orn, Cit, Tau) in root were decreased in LN treatment as compared to CK; however, Thr increased in both shoot and root of LN seedlings (Table 2). Among these amino acids Ala, $\beta$-Ala and Lys are the amino acids 
which co-decreased significantly in shoot and root following the order $\mathrm{CK}>\mathrm{ON}>\mathrm{LN}$ (Table 2) As far as mineral accumulation in shoot and root of oat seedlings is concerned, $\mathrm{P}, \mathrm{Mg}, \mathrm{Na}, \mathrm{Cu}, \mathrm{B}, \mathrm{Mn}$ and $\mathrm{Zn}$ concentration increased while that of $\mathrm{K}$ and $\mathrm{S}$ decreased in LN root and shoot as compared to CK and ON (Table 3).
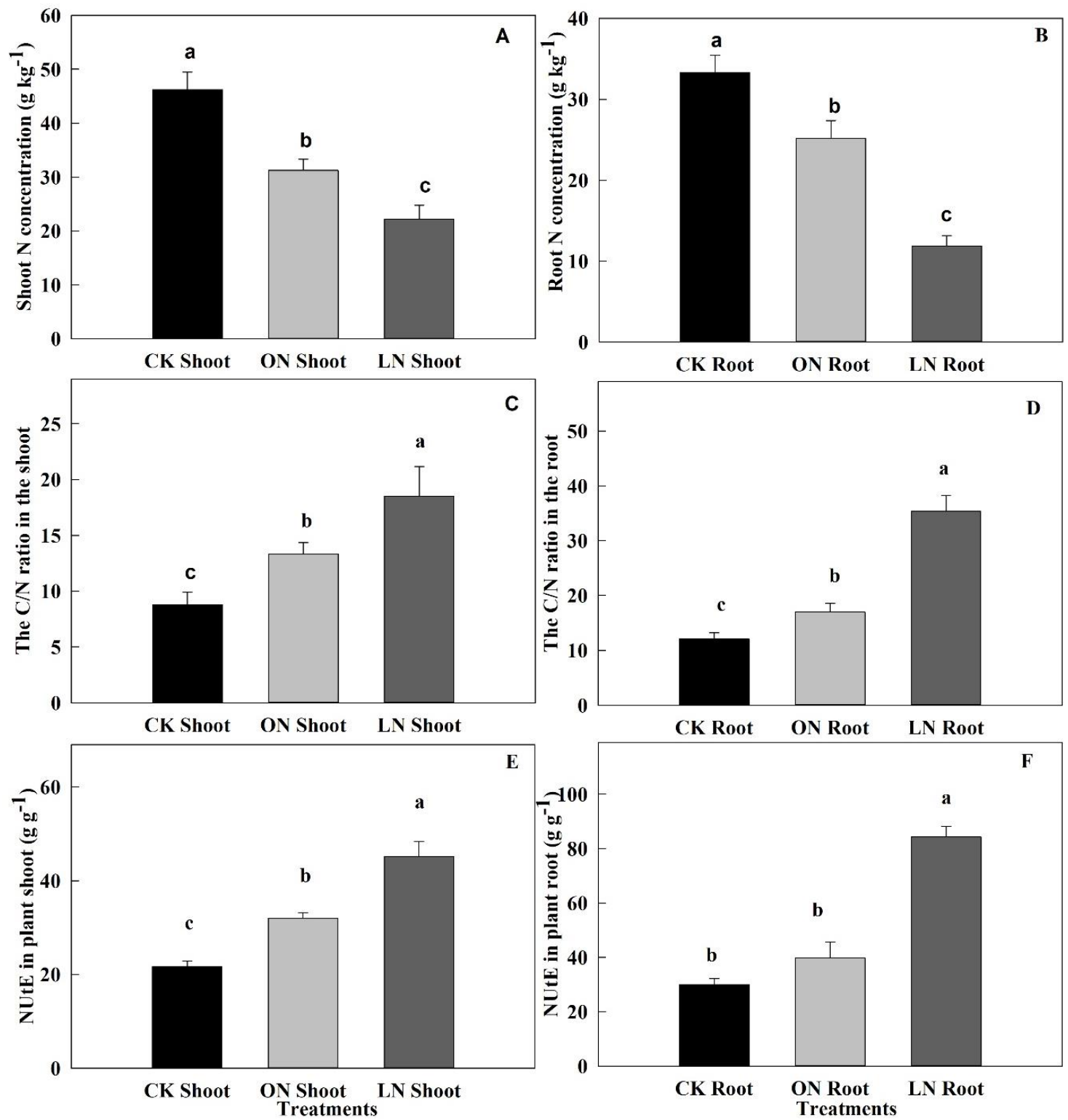

Figure 5. $N$ accumulation in oat plant parts under different treatment. Shoot $N$ concentration $(A)$, root $N$ concentration $(B), C / N$ ratio in the shoot $(C), C / N$ ratio in the root $(D), N U t E$ in the shoot $(E)$, and NUtE in the root $(F)$ in response to $L N$. Error bars represented standard error of six biological replicates, different letters indicate significant differences $(P<0.05)$. Treatment $C K=$ control, $O N=$ organic $N, L N=$ low $N$

\section{Alterations in hormone accumulation}

Plant growth and development is regulated by plant hormones (Beveridge et al., 1997; Marsch-Martinez and de Folter, 2016). In this study, the concentrations of indole- 
3-acetic acid (IAA/auxin), gibberellic acid (GA3) and zeatin-riboside (ZR; a kind of cytokinins) decreased in shoots of $\mathrm{ON}$ as well as $\mathrm{LN}$ treated oat seedlings (Fig. 7A, C, $G)$. In contrast to shoot, the concentration of aforementioned hormones reversed and increased in roots of LN treated seedlings as compared to CK and ON (Fig. 7B, D, H). On the other hand, abscisic acid concentration increased in both ON and LN treated shoots as compared to $\mathrm{CK}(\mathrm{CK}<\mathrm{ON}<\mathrm{LN})$ with $\mathrm{LN}$ treated shoots depicting the highest number than the rest and vice versa in roots (Fig. $7 E, F)$.

\section{Discussion}

Nitrogen is an important macronutrient for plant growth and development. As an imperative component of chlorophyll, it is required for proper functioning of photosynthesis apparatus whereas being a building block of peptides, it is required for protein biosynthesis (Hirel et al., 2007; Wang et al., 2012). Owing to the heterogeneous availability of nitrogen in soil, the adaptation of plants to uptake nitrogen from its immediate vicinity becomes vital (Wang et al., 2007), hence different plants respond to external $\mathrm{N}$ availability differentially through physiological, morphological and molecular adaptations. Legumes form nodules to fix atmospheric nitrogen whereas nonlegumes like maize, rice and foxtail millet may alter their root architecture in order to explore the nitrogen patches in soil (Postgate, 1998; Wang et al., 2003; Chun et al., 2005a; Nadeem et al., 2018). Long-term nitrogen deficiency hinders plant root and shoot growth (Chun et al., 2005b; Guo et al., 2005; Goron et al., 2015). It is well established that rice and wheat crops produced longer root system under nitrogen deprivation in order to explore as much soil surface as possible to reach nitrogen rich patches (Cai et al., 2012; Guo et al., 2014). Oat can be cultivated in marginal lands with little nutrient and/or water requirements. The morphological and physiological adaptation of oat to chemical nitrogen $(\mathrm{CK})$, organic nitrogen $(\mathrm{ON})$ and low nitrogen (LN) remains unknown to date. In this study, oat produced the longest root system, shortest shoot and smallest leaf area under LN as compared to $\mathrm{CK}$ and $\mathrm{ON}$ whereas it produced the longer root system, shorter shoot and smaller leaf area under ON with respect to $\mathrm{CK}$ (Figs. $1 A-E$ and $2 A, B$ ) as a primary response to various nitrogen regimes.

Table 2. Amino acid concentrations ( $\mu \mathrm{mol} \mathrm{g}^{-1} \mathrm{FW}$ ) in shoot and root of oat grown hydroponically low $N$, organic $N$ and Control (high chemical $N$ ) condition

\begin{tabular}{c|c|c|c|c|c|c}
\hline \multirow{2}{*}{ Amino acid } & \multicolumn{3}{|c|}{ Shoot } & \multicolumn{3}{c}{ Root } \\
\cline { 2 - 7 } & CK & ON & LN & CK & ON & LN \\
\hline Glutamic acidGlu & $2 \cdot 72 \pm 0 \cdot 80 \mathrm{a}$ & $1 \cdot 39 \pm 0 \cdot 20 \mathrm{~b}$ & $1 \cdot 27 \pm 0 \cdot 11 \mathrm{~b}$ & $0 \cdot 76 \pm 0 \cdot 24 \mathrm{a}$ & $0 \cdot 54 \pm 0 \cdot 13 \mathrm{~b}$ & $0 \cdot 29 \pm 0 \cdot 15 \mathrm{c}$ \\
Serine (Ser) & $1 \cdot 42 \pm 0 \cdot 04 \mathrm{a}$ & $1 \cdot 25 \pm 0 \cdot 25 \mathrm{~b}$ & $1 \cdot 09 \pm 0 \cdot 17 \mathrm{c}$ & $1 \cdot 02 \pm 0 \cdot 24 \mathrm{a}$ & $0 \cdot 91 \pm 0 \cdot 16 \mathrm{a}$ & $0 \cdot 75 \pm 0 \cdot 15 \mathrm{~b}$ \\
Glutamine (Gln) & $1 \cdot 12 \pm 0 \cdot 80 \mathrm{a}$ & $0 \cdot 78 \pm 0 \cdot 27 \mathrm{~b}$ & $0 \cdot 63 \pm 0 \cdot 25 \mathrm{~b}$ & $3 \cdot 61 \pm 0 \cdot 97 \mathrm{a}$ & $1 \cdot 85 \pm 0 \cdot 18 \mathrm{~b}$ & $1 \cdot 68 \pm 0 \cdot 64 \mathrm{~b}$ \\
Arginine (Arg) & $0 \cdot 06 \pm 0 \cdot 01 \mathrm{a}$ & $0 \cdot 06 \pm 0 \cdot 01 \mathrm{a}$ & $0 \cdot 07 \pm 0 \cdot 01 \mathrm{a}$ & $0 \cdot 04 \pm 0 \cdot 01 \mathrm{c}$ & $0 \cdot 07 \pm 0 \cdot 02 \mathrm{~b}$ & $0 \cdot 13 \pm 0 \cdot 06 \mathrm{a}$ \\
Alanine (Ala) & $1 \cdot 70 \pm 0 \cdot 04 \mathrm{a}$ & $1 \cdot 67 \pm 0 \cdot 66 \mathrm{ab}$ & $1 \cdot 17 \pm 0 \cdot 14 \mathrm{c}$ & $1 \cdot 25 \pm 0 \cdot 81 \mathrm{a}$ & $0 \cdot 62 \pm 0 \cdot 13 \mathrm{~b}$ & $0 \cdot 45 \pm 0 \cdot 03 \mathrm{c}$ \\
BAlanine (B-Ala) & $0.62 \pm 0.02 \mathrm{a}$ & $0.51 \pm 0.01 \mathrm{~b}$ & $0.40 \pm 0.03 \mathrm{c}$ & $0.33 \pm 0.03 \mathrm{a}$ & $0.17 \pm 0.01 \mathrm{~b}$ & $0.09 \pm 0.01 \mathrm{c}$ \\
Valine (Val) & $0 \cdot 27 \pm 0 \cdot 01 \mathrm{a}$ & $0 \cdot 18 \pm 0 \cdot 04 \mathrm{~b}$ & $0 \cdot 18 \pm 0 \cdot 00 \mathrm{~b}$ & $0 \cdot 69 \pm 0 \cdot 26 \mathrm{a}$ & $0 \cdot 47 \pm 0 \cdot 20 \mathrm{~b}$ & $0 \cdot 61 \pm 0 \cdot 18 \mathrm{a}$ \\
Aspartic acid (Asp) & $2.88 \pm 0.28 \mathrm{a}$ & $1.98 \pm 0.28 \mathrm{~b}$ & $1.49 \pm 0.13 \mathrm{c}$ & $0 \cdot 43 \pm 0 \cdot 06 \mathrm{a}$ & $0 \cdot 36 \pm 0 \cdot 13 \mathrm{ab}$ & $0 \cdot 21 \pm 0 \cdot 01 \mathrm{~b}$ \\
Asparagine (Asn) & $1 \cdot 55 \pm 0 \cdot 66 \mathrm{a}$ & $1 \cdot 53 \pm 0 \cdot 75 \mathrm{a}$ & $1 \cdot 15 \pm 0 \cdot 68 \mathrm{~b}$ & $1 \cdot 18 \pm 0 \cdot 70 \mathrm{a}$ & $1 \cdot 18 \pm 0 \cdot 34 \mathrm{a}$ & $0 \cdot 74 \pm 0 \cdot 43 \mathrm{~b}$ \\
Lysine (Lys) & $0 \cdot 09 \pm 0 \cdot 00 \mathrm{a}$ & $0 \cdot 07 \pm 0 \cdot 01 \mathrm{ab}$ & $0 \cdot 03 \pm 0 \cdot 00 \mathrm{c}$ & $0 \cdot 06 \pm 0 \cdot 01 \mathrm{~b}$ & $0 \cdot 09 \pm 0 \cdot 02 \mathrm{a}$ & $0 \cdot 03 \pm 0 \cdot 01 \mathrm{c}$ \\
Isoleucine (Ile) & $0 \cdot 07 \pm 0 \cdot 00 \mathrm{a}$ & $0 \cdot 05 \pm 0 \cdot 00 \mathrm{~b}$ & $0 \cdot 023 \pm 0 \cdot 01 \mathrm{c}$ & $0 \cdot 45 \pm 0 \cdot 16 \mathrm{a}$ & $0 \cdot 43 \pm 0 \cdot 24 \mathrm{a}$ & $0 \cdot 32 \pm 0 \cdot 20 \mathrm{~b}$ \\
Methionine (Met) & $0 \cdot 03 \pm 0 \cdot 00$ & $0 \cdot 00 \pm 0 \cdot 00$ & $0 \cdot 01 \pm 0 \cdot 00$ & $0 \cdot 1 \pm 0 \cdot 07 \mathrm{a}$ & $0 \cdot 03 \pm 0 \cdot 04 \mathrm{c}$ & $0 \cdot 07 \pm 0 \cdot 02 \mathrm{~b}$ \\
Threonine (Thr) & $0 \cdot 51 \pm 0 \cdot 10 \mathrm{c}$ & $0 \cdot 71 \pm 0 \cdot 16 \mathrm{~b}$ & $1.49 \pm 0.01 \mathrm{a}$ & $0 \cdot 70 \pm 0 \cdot 36 \mathrm{c}$ & $0 \cdot 95 \pm 0 \cdot 45 \mathrm{~b}$ & $1 \cdot 14 \pm 0 \cdot 36 \mathrm{a}$ \\
Glycine (Gly) & $0 \cdot 10 \pm 0 \cdot 01 \mathrm{~b}$ & $0 \cdot 19 \pm 0 \cdot 05 \mathrm{a}$ & $0 \cdot 08 \pm 0 \cdot 02 \mathrm{~b}$ & $0 \cdot 23 \pm 0 \cdot 06 \mathrm{~b}$ & $0 \cdot 48 \pm 0 \cdot 05 \mathrm{a}$ & $0 \cdot 18 \pm 0 \cdot 02 \mathrm{~b}$
\end{tabular}




\begin{tabular}{c|c|c|c|c|c|c|c} 
Tyrosine (Tyr) & $0 \cdot 04 \pm 0 \cdot 01 \mathrm{a}$ & $0 \cdot 01 \pm 0 \cdot 01 \mathrm{~b}$ & $0 \cdot 02 \pm 0 \cdot 00 \mathrm{~b}$ & $0 \cdot 16 \pm 0 \cdot 04 \mathrm{a}$ & $0 \cdot 12 \pm 0 \cdot 06 \mathrm{~b}$ & $0 \cdot 09 \pm 0 \cdot 04 \mathrm{~b}$ \\
Tryptophan (Trp) & $0 \cdot 11 \pm 0 \cdot 03 \mathrm{a}$ & $0.06 \pm 0 \cdot 02 \mathrm{~b}$ & $0 \cdot 04 \pm 0 \cdot 00 \mathrm{~b}$ & $0 \cdot 17 \pm 0 \cdot 09 \mathrm{a}$ & $0 \cdot 15 \pm 0 \cdot 08 \mathrm{~b}$ & $0 \cdot 14 \pm 0 \cdot 02 \mathrm{~b}$ \\
Phenylalanine (Phe) & $0 \cdot 07 \pm 0 \cdot 00 \mathrm{a}$ & $0.03 \pm 0 \cdot 01 \mathrm{~b}$ & $0.02 \pm 0 \cdot 01 \mathrm{~b}$ & $0 \cdot 04 \pm 0 \cdot 02 \mathrm{a}$ & $0 \cdot 04 \pm 0 \cdot 02 \mathrm{a}$ & $0 \cdot 03 \pm 0 \cdot 00 \mathrm{a}$ \\
Histidine (His) & $0 \cdot 20 \pm 0 \cdot 03 \mathrm{a}$ & $0 \cdot 10 \pm 0 \cdot 02 \mathrm{~b}$ & $0 \cdot 09 \pm 0 \cdot 01 \mathrm{~b}$ & $0 \cdot 27 \pm 0 \cdot 12 \mathrm{a}$ & $0 \cdot 17 \pm 0 \cdot 09 \mathrm{~b}$ & $0 \cdot 15 \pm 0 \cdot 03 \mathrm{~b}$ \\
Leucine (Leu) & $0.04 \pm 0 \cdot 01 \mathrm{a}$ & $0 \cdot 02 \pm 0 \cdot 001 \mathrm{ab}$ & $0 \cdot 01 \pm 0 \cdot 01 \mathrm{~b}$ & $0 \cdot 61 \pm 0 \cdot 35 \mathrm{a}$ & $0 \cdot 45 \pm 0 \cdot 26 \mathrm{~b}$ & $0 \cdot 06 \pm 0 \cdot 21 \mathrm{c}$ \\
Ornithine (Orn) & $0.14 \pm 0.01 \mathrm{a}$ & $0.09 \pm 0.02 \mathrm{~b}$ & $0.06 \pm 0.00 \mathrm{~b}$ & $0.12 \pm 0.01 \mathrm{a}$ & $0.10 \pm 0.02 \mathrm{a}$ & $0.04 \pm 0.00 \mathrm{~b}$ \\
Citrulline (Cit) & $0.12 \pm 0.01 \mathrm{a}$ & $0.11 \pm 0.01 \mathrm{a}$ & $0.07 \pm 0.00 \mathrm{~b}$ & $0.13 \pm 0.01 \mathrm{a}$ & $0.09 \pm 0.01 \mathrm{~b}$ & $0.06 \pm 0.00 \mathrm{~b}$ \\
Taurine (Tau) & $0.02 \pm 0.00 \mathrm{a}$ & $0.01 \pm 0.00 \mathrm{~b}$ & $0.009 \pm 0.00 \mathrm{~b}$ & $0.04 \pm 0.01 \mathrm{a}$ & $0.02 \pm 0.001 \mathrm{ab}$ & $0.01 \pm 0.00 \mathrm{~b}$ \\
\hline
\end{tabular}

Tissue samples were taken just prior to harvesting. In each column lower case letters indicated the significant differences between different types of treatments at $\mathrm{P}<0.05$ level. Values show Standard errors (SE) \pm mean of four replicates. $\mathrm{CK}=100 \% \mathrm{chemical}$ $\mathrm{N}, \mathrm{ON}=100 \%$ organic $\mathrm{N}$ and $\mathrm{LN}=$ Low $\mathrm{N}$
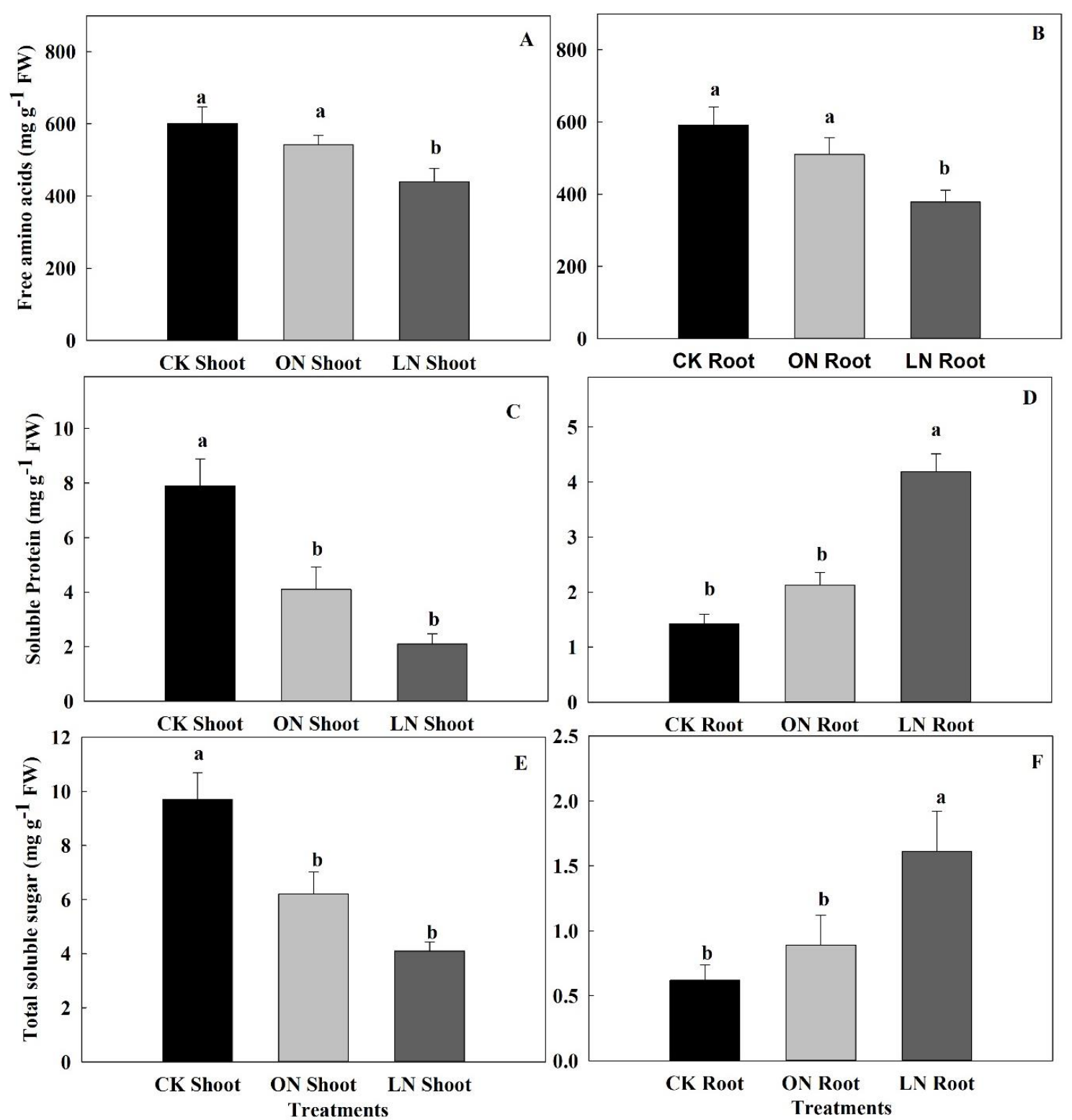

Figure 6. Concentrations of $N$ metabolites in shoot and root of oat plant under different $N$ treatment, free amino acids $(A, B)$, soluble proteins $(C, D)$, and soluble sugars $(E, F)$. Error bars represented standard error of six biological replicates, different letters indicate significant differences $(P<0.05)$. Treatment $C K=$ control, $O N=$ organic $N, L N=$ low $N$ 

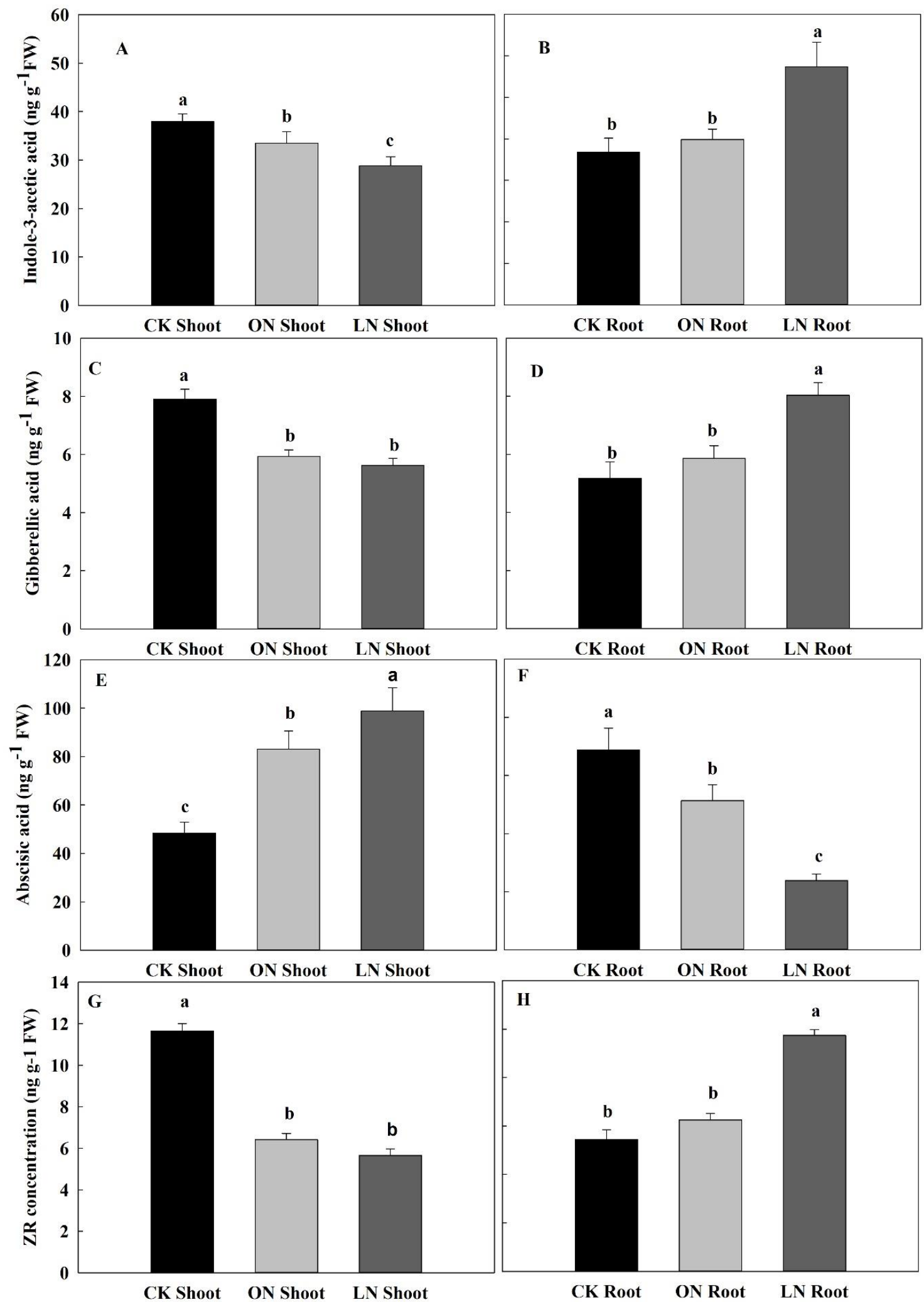

Figure 7. Effects of $N$ deficiency on hormone accumulation in the oat shoot and root. $(A, B)$ IAA. $(C, D) . G A .(E, F) . A B A,(G, H) . Z R$. Error bars represented standard error of six biological replicates, different letters indicate significant differences $(P<0.05)$. Treatment $C K=$ control, $O N=$ organic $N, L N=$ low $N$ 
Table 3. Minerals concentration in Shoot and root after harvesting of oat under different treatment

\begin{tabular}{c|c|c|c|c|c|c|c|c|c|c|c|c|c}
\hline & \multirow{2}{*}{ Treatment } & $\mathbf{P}$ & $\mathbf{K}$ & $\mathbf{C a}$ & $\mathbf{M g}$ & $\mathbf{F e}$ & $\mathbf{N a}$ & $\mathbf{C u}$ & $\mathbf{Z n}$ & $\mathbf{M n}$ & $\mathbf{S}$ & $\mathbf{B}$ \\
\cline { 3 - 11 } & & $\mathbf{9}$ & $6750 \mathrm{c}$ & $31900 \mathrm{a}$ & $2463.3 \mathrm{c}$ & $1345 \mathrm{c}$ & $115.83 \mathrm{c}$ & $131.5 \mathrm{c}$ & $3.88 \mathrm{c}$ & $12.82 \mathrm{c}$ & $10.85 \mathrm{c}$ & $2698.33 \mathrm{a}$ & $3.85 \mathrm{c}$ \\
\multirow{3}{*}{ Shoot } & ON & $8016.67 \mathrm{~b}$ & $29583.3 \mathrm{~b}$ & $5300 \mathrm{a}$ & $1865 \mathrm{~b}$ & $229.5 \mathrm{a}$ & $330.5 \mathrm{~b}$ & $5.73 \mathrm{~b}$ & $15.27 \mathrm{~b}$ & $18.53 \mathrm{~b}$ & $2451.66 \mathrm{~b}$ & $5.48 \mathrm{~b}$ \\
& $\mathbf{L N}$ & $9133.33 \mathrm{a}$ & $25600 \mathrm{c}$ & $5116.67 \mathrm{~b}$ & $1983.3 \mathrm{a}$ & $170.5 \mathrm{~b}$ & $687.5 \mathrm{a}$ & $6.25 \mathrm{a}$ & $20.3 \mathrm{a}$ & $39.17 \mathrm{a}$ & $2263.33 \mathrm{c}$ & $6.91 \mathrm{a}$ \\
\hline \multirow{3}{*}{ Root } & CK & $5676.54 \mathrm{~b}$ & $17733.15 \mathrm{a}$ & $2457.52 \mathrm{c}$ & $1432.9 \mathrm{c}$ & $256.57 \mathrm{c}$ & $1508.51 \mathrm{c}$ & $4.7 \mathrm{c}$ & $39.66 \mathrm{~b}$ & $14.1 \mathrm{c}$ & $3915.43 \mathrm{a}$ & $3.26 \mathrm{c}$ \\
& ON & $5838.3 \mathrm{ab}$ & $12400 \mathrm{~b}$ & $5075 \mathrm{a}$ & $2592.5 \mathrm{~b}$ & $1105 \mathrm{a}$ & $3000 \mathrm{~b}$ & $6.65 \mathrm{~b}$ & $42.7 \mathrm{~b}$ & $46.75 \mathrm{~b}$ & $2997.5 \mathrm{~b}$ & $3.91 \mathrm{~b}$ \\
& LN & $6500 \mathrm{a}$ & $10625 \mathrm{~b}$ & $2750 \mathrm{~b}$ & $5766.67 \mathrm{a}$ & $438.83 \mathrm{~b}$ & $5877.5 \mathrm{a}$ & $13.775 \mathrm{a}$ & $60 \mathrm{a}$ & $56.63 \mathrm{a}$ & $1938.33 \mathrm{c}$ & $5.84 \mathrm{a}$ \\
\hline
\end{tabular}

In each column lower case lettering is used to show the significant differences between different types of treatments at $\mathrm{P}<0.05$ level. CK $=100 \%$ chemical $\mathrm{N}, \mathrm{ON}=100 \%$ organic $\mathrm{N}$ and $\mathrm{LN}=$ Low $\mathrm{N}$

\section{Large root system, hormonal variations and subsequent biomass accumulation in oat}

Nitrogen starvation produced larger root system in maize (Han et al., 2015). Roots are the means by which plants uptake nutrients and these are the organs directly sensing their availability. In current study, oat seedlings exposed to LN treatment produced largest root system in terms of crown root number and length, lateral root number, length and density, and total root length. In ON treated seedlings, lateral root number, length and total root length increased as compared to $\mathrm{CK}$ only (Table 1). The enhancement of total root system of oat under low nitrogen and lateral root system under ON could be due to increased carbon allocation from shoot towards the root as shown by subsequently decreased shoot dry weight and increased root dry weight and root to shoot ratio under $\mathrm{ON}$ and $\mathrm{LN}$ treatments (Fig. 2C-E). Consistent with the previous studies (Han et al., 2015; Nadeem et al., 2018) the specific root length (SRL) of oat was found to be $6227 \mathrm{~cm} \mathrm{~g}^{-1}, 5760 \mathrm{~cm} \mathrm{~g}^{-1}$, and $7145 \mathrm{~cm} \mathrm{~g}^{-1}$ under CK, ON and LN treatments respectively. Extremely large SRL of oat under LN indicated its adaptation and primary response strategy to explore nitrogen under nitrogen limitation conditions. On one hand the increased total root length under LN was due to increased crown root number and length, and lateral root number and length whereas on the other hand it could also be due to decreased average root diameter (Table 1) which illustrated the longitudinal growth of roots. It is well established now that if only $\mathrm{NO}_{3}{ }^{-}$used as a source of $\mathrm{N}$ (no $\mathrm{NH}_{4}{ }^{+}$) $\mathrm{LN}$ caused reduced total root length including crown and lateral root length and number in maize (Wang et al., 2005; Tian et al., 2008; Gao etal.,2015). Hence the differential response of oat to $\mathrm{ON}$ treatment in terms of root system architecture remained consistent with previous findings and it could be the innate response of oat where different plant species respond to different nitrogen sources differentially. A significant positive correlation was revealed between concentration of $\mathrm{P}, \mathrm{Mg}, \mathrm{Cu}, \mathrm{Mn}, \mathrm{Zn}, \mathrm{B}$ and $\mathrm{Na}$ in root tissue with root morphological traits (Table A8). These attributes possibly influenced the ion balance within oat root leading to alterations in root morphology which needs to be further investigated in future. The most crucial role played by hormones is to regulate the speed of growth and development of the individual parts of the plant to adapt the surrounding environment (Wolters and Jürgens, 2009). Auxin is the most essential hormone which modulates different physiological processes of the plants, i.e. cell division, elongation and differentiation of different parts of plant (Reed, 2001) including root growth and development regulation (Jiang and Feldman, 2003). Gibberellic acids have crucial role 
of plant organ differentiation and development, regulation of the tall phenotypic character of plants (Yamaguchi, 2008), shoot internode extension, enlargement of leaf surface area and enhancement of apical dominance. Cytokinins help to regulate the mobilization of carbohydrate and N signaling (Ashikari et al., 2005; Sakakibara, 2006). On the other hand, the special cytokinin "zeatin-riboside" helps in the bio-synthesis and maintenance of auxin (Jones et al., 2010). IAA, GA3 and ZR decreased in ON and LN shoot whereas increased in respective roots in this study (Fig. 7A-D, $G-H)$. This finding is in accordance to shorter shoot and larger root system observed in $\mathrm{ON}$ and LN treated oat seedlings (Fig. 2A; Table 1). ABA stimulates plant capacity to cell division or intermediates adaptive responses to the stress environment as well as $\mathrm{N}$ starvation (Chin and Beevers, 1970; Santner et al., 2009). This study found increased ABA concentration in $\mathrm{LN}$ shoot followed by $\mathrm{ON}$ and $\mathrm{CK}$ shoot whereas, in total contrast to shoot, the concentration of ABA totally reversed in roots of oat seedlings having least concentration under LN followed by $\mathrm{ON}$ and CK (Fig. 7E, F). This finding illustrated that oat roots were not under stress in LN condition and can act as the basis to develop plant varieties which can adapt to stress conditions efficiently.

\section{Nitrogen concentration, mineral accumulation and photosynthesis}

Chlorophyll (Chl) concentration in plant leaves affects photosynthesis by regulating photosynthetic capacity and ultimately plant growth (Li et al., 2018). The most important source of energy required for plant growth is photosynthesis (Baker, 2008). A photosynthetic reaction is generally split into three steps: primary reaction, electron transport and photophosphorylation, and carbon assimilation. $\mathrm{Chl} \mathrm{a}$ and $\mathrm{Chl} b$ are the most essential pigments to complete primary reaction. Chl a can absorb red to orange light whereas $\mathrm{Chl} b$ absorbs blue to purple light. SPAD value, $\mathrm{Chl} \mathrm{a}, \mathrm{Chl} \mathrm{b}$ and total carotenoids decreased under ON and LN treatment in current study (Fig. 3A-D) which resulted in subsequent decreases in net photosynthesis $(\mathrm{Pn})$, intercellular carbon dioxide (Ci), transpiration rate (Tr) and stomatal conductance (gs) (Fig. 4A-D). The reason to this could be the decreased $\mathrm{N}$ concentration in shoot of oat under ON and LN treatment (Fig. 5A) which could have hindered chlorophyll biosynthesis and disturbed the functioning of photosynthesis apparatus. These findings are consistent with previous study in sorghum (Muchow and Sinclair, 1994) and corn (Zhao et al., 2003; Long et al., 2004). Another possibility could have been the gradually reduced leaf area due to less $\mathrm{N}$ accumulation under ON and LN (Fig. 1B) which provided less surface area for light absorption and hence resulted in malfunctioned photosynthetic bio-machinery similar to maize (Zhao et al., 2003). Another reason which could have led to decreased photosynthesis was the reduction of potassium $(\mathrm{K})$ concentration and increment in sodium (Na) concentration in LN shoot (Table 3). Lower the ratio of $\mathrm{K} / \mathrm{Na}$, lower will be the opening of stomata (Willmer et al., 1983) which could have reduced stomatal conductance in current study gradually from $\mathrm{CK}$ to $\mathrm{LN}$ conditions.

\section{Nitrogen metabolism, carbon accumulation and re-allocation}

In the process of inorganic $\mathrm{N}$ assimilation amides and amino acids are the first stable products (Yang et al., 2015) and act as the building blocks for proteins. The changes in several amino acids concentration or total free amino acids accumulation regulates many processes in plants including the $\mathrm{N}$ metabolism process and storage (Miller and Cramer, 2005; Cañas et al., 2009). The free amino acids concentration in the plant shoot 
and root tissues has been reported to fluctuate significantly with different $\mathrm{N}$ levels and sources. A higher $\mathrm{N}$ dose can boost the concentration of total free amino-acid in leaves of many plant species (Yang et al., 2015). The total free amino acids concentration in wheat root was dramatically decreased due removal of the $\mathrm{N}$ from the nutrient solution (Rodgers and Barneix, 1989) but drastically increased upon resupply of $\mathrm{NH}_{4}{ }^{+}$or $\mathrm{NO}_{3}{ }^{-}$ the N-deficient plants (Causin and Barneix, 1993). Free amino acids concentration in shoot and root of oat seedlings in current study decreased in $\mathrm{ON}$ and LN treatments (Fig. 6A, B) which is consistent with related low nitrogen concentrations in shoot and root under $\mathrm{ON}$ and LN (Fig. 5A, B) resulting in lesser biosynthesis of amino acids. Reduced free amino acids concentration resulted in reduced soluble proteins biosynthesis in shoot under $\mathrm{ON}$ and $\mathrm{LN}$ treatments respectively (Fig. 6C). Similar trend was observed for total soluble sugars concentration in shoot under ON and LN respectively (Fig. 6E). In contrast to shoot, total soluble sugars and total soluble proteins concentrations increased in root of oat seedling under both $\mathrm{ON}$ and LN treatment (Fig. 6D, F) probably due to the co-transport of carbon and amino acids to nitrogen deficient root. This phenomenon resulted in increased carbon and nitrogen metabolites accumulation in nitrogen deficient root leading to a larger root system (Fig. 1B, D, E) to cope nitrogen limitation. There occurred a positive correlation of total soluble proteins and total soluble sugars with shoot and root dry weight (Fig. 8B, C, E, $F$ ) whereas the correlation of free amino acids with shoot dry weight was positive but that of with root dry weight remained negative (Fig. 8A, B) which again emphasized our argument of possible co-transport of carbon and $\mathrm{N}$-metabolites to $\mathrm{N}$-deficient root as an adaptive response to cope low nitrogen.
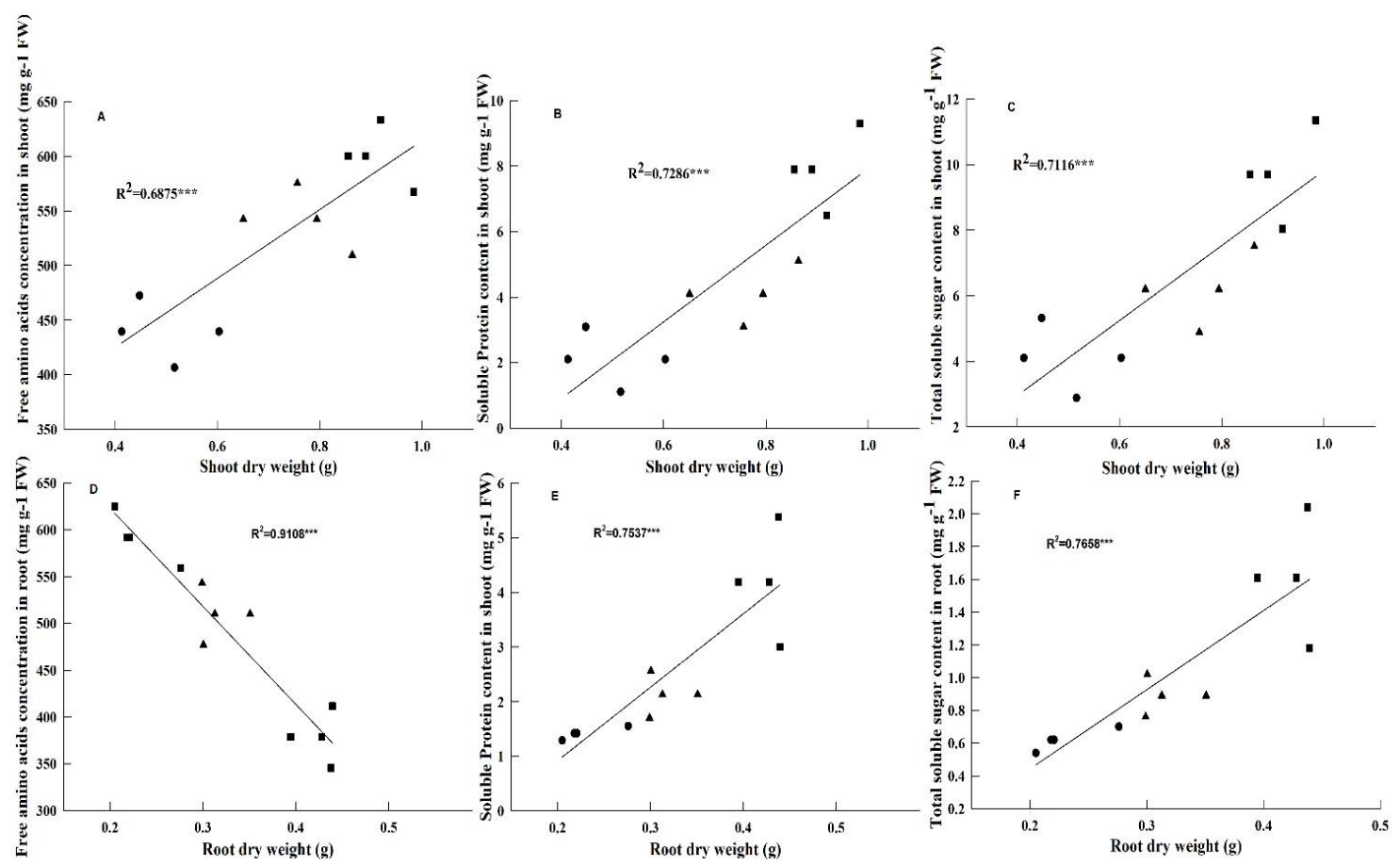

Figure 8. Relation between $N$ metabolites and root and shoot dry weight of oat. Free amino acids and shoot dry weight (A), SOLUBLE protein and shoot dry weight (B), soluble sugar and shoot dry weight $(C)$, free amino acids and root dry weight $(D)$, soluble protein and root dry weight $(E)$ and soluble sugar and root dry weight $(F)$. Values were obtained from four replicates 
Furthermore, free amino acids to $\mathrm{N}$ concentration ratio, total soluble proteins to $\mathrm{N}$ concentration ratio and total soluble sugars to $\mathrm{N}$ concentration ratio significantly increased in LN roots (Table 4) which further elucidated the shoot to root transport of carbon and nitrogen metabolites in order to let oat roots acclimatize to $\mathrm{N}$-deprivation. In the mechanism of ammonium assimilation, the first product is glutamine and glutamate is its precursor whereas asparagine, aspartate and serine generally form the dominant pool of the amino acids in the leaves of many plants (Yang et al., 2015). Sometimes other amino acids may also become dominant depending on the plant species and $\mathrm{N}$ concentration of the surrounding environment (Xu et al., 2012; Pratelli and Pilot, 2014). Particularly, Gln and Asn are the most crucial mediators for synthesis and integration of different amino acids and also storage proteins (Miller and Cramer, 2005; Seebauer et al., 2004). Lower $\mathrm{N}$ concentration in shoot and root might have contributed to decreased biosynthesis of Gln (Table 2). Similar was the case with Asn in both shoot and root which could have altered protein synthesis negatively as revealed by decreased soluble proteins concentration in the LN shoot (Table 2, Fig. 6C). Altogether, the amino acid profile depicted a complicated regulation of N-metabolism which needs to be further dissected in future studies. shoot due to Carbon to nitrogen ratio was the highest in shoot as well as root under $\mathrm{LN}$ followed by ON treatment (Fig. 5C, D). Similar was the trend of nitrogen utilization efficiency (NUtE) (Fig. 5E, F). These results further suggested the higher accumulation of carbon in shoot and root and subsequent reallocation within the oat tissues as the $\mathrm{N}$ availability shifted from $\mathrm{CK}$ to $\mathrm{LN}$ conditions.

Table 4. Nitrogen metabolites/ $N$ concentration ratio in oat shoot and root after harvesting

\begin{tabular}{c|c|c|c|c}
\hline & Treatment & $\begin{array}{c}\text { Free amino acids/N } \\
\text { concentration ratio }\end{array}$ & $\begin{array}{c}\text { Soluble protein/N } \\
\text { concentration ratio }\end{array}$ & $\begin{array}{c}\text { Soluble sugar/N } \\
\text { concentration ratio }\end{array}$ \\
\hline \multirow{3}{*}{ Shoot } & CK & $12.99 \pm 0.5 \mathrm{c}$ & $0.17 \pm 0.01 \mathrm{a}$ & $0.21 \pm 0.01 \mathrm{a}$ \\
& ON & $17.37 \pm 0.84 \mathrm{~b}$ & $0.13 \pm 0.01 \mathrm{ab}$ & $0.2 \pm 0.01 \mathrm{a}$ \\
& LN & $19.88 \pm 1.83 \mathrm{a}$ & $0.096 \pm 0.01 \mathrm{~b}$ & $0.19 \pm 0.02 \mathrm{a}$ \\
\hline \multirow{3}{*}{ Root } & CK & $17.76 \pm 0.75 \mathrm{~b}$ & $0.043 \pm 0.001 \mathrm{~b}$ & $0.019 \pm 0.001 \mathrm{~b}$ \\
& ON & $20.52 \pm 1.61 \mathrm{~b}$ & $0.085 \pm 0.001 \mathrm{~b}$ & $0.04 \pm 0.002 \mathrm{~b}$ \\
& LN & $31.95 \pm 1.4 \mathrm{a}$ & $0.35 \pm 0.04 \mathrm{a}$ & $0.14 \pm 0.01 \mathrm{a}$ \\
\hline
\end{tabular}

In each column lower case lettering is used to show the significant differences between different types of treatments at $\mathrm{P}<0.05$ level. Values show Standard errors $(\mathrm{SE}) \pm$ mean of four replicates. $\mathrm{CK}=100 \%$ chemical $\mathrm{N}, \mathrm{ON}=100 \%$ organic $\mathrm{N}$ and $\mathrm{LN}=$ Low $\mathrm{N}$

\section{Conclusion}

Nitrogen, a vital macronutrient for crop growth and development, is often subjected to losses through various means and causes environmental hazards through its excessive deposition in the ecosystem. Hence, nitrogen use efficient crops can minimize the use of chemical nitrogen and thus reverse the environmental deteriorations. In this study, Oat (a cereal crop) was studied for its adaptation to different nitrogen regimes $(\mathrm{CK}, \mathrm{ON}$, $\mathrm{LN})$. Root dry weight, R/S ratio, $\mathrm{C} / \mathrm{N}$ ratio and $\mathrm{NUtE}$ increased under $\mathrm{LN}$ treatment which indicated the allocation of carbon to continuously growing root as suggested by increased crown root number and length, lateral root number and length, and total root length under low nitrogen. Highest levels of total soluble proteins and total soluble sugars were in total contrast to lowest $\mathrm{N}$ concentration in roots under $\mathrm{LN}$ which further emphasized the carbon provision of roots at the cost of minimum photosynthesis. 
Furthermore, highest levels of IAA, GA3 and ZR in Low nitrogen roots was perhaps the innate adaptive strategy of oat allowing the roots to expand under low nitrogen stress as shown by highest level of abscisic acid. Altogether, these findings suggested that oat is an extremely nitrogen use efficient crop which can be well adapted to N-poor soils.

Acknowledgements. We thank Lili Chen, Yubin Zhao, Nurun Nabi, Ashiqur Rahman, Faisal Hayat Maken and all the lab-fellows and workers for their kind help throughout the experiment. This study was supported by the China Agriculture Research System (CARS-08-B-1)

Author contributions. TAK, FN, ZZ, and YH designed the experiment. TAK, FN, YG, and YY, performed the research. TAK and FN analyzed the data and wrote the manuscript. XW, ZZ and YH revised the manuscript. All authors approved the final manuscript.

\section{REFERENCES}

[1] Ashikari, M., Sakakibara, H., Lin, S., Yamamoto, T., Takashi, T., Nishimura, A., Angeles, E. R., Qian, Q., Kitano, H., Matsuoka, M. (2005): Cytokinin oxidase regulates rice grain production. - Science 309(5735): 741-745.

[2] Ata-Ul-Karim, S. T., Zhu, Y., Yao, X., Cao, W. (2014): Determination of critical nitrogen dilution curve based on leaf area index in rice. - Field Crops Research 167: 76-85.

[3] Baker, N. R. (2008): Chlorophyll fluorescence: a probe of photosynthesis in vivo. Annual Review of Plant Biology 59: 89-113.

[4] Baker, W. H., Thompson, T. L. (1992): Determination of total nitrogen in plant samples by Kjeldahl. Plant analysis reference procedures for the southern region of the United States. - Southern Cooperative Series Bulletin 368: 13-16.

[5] Beveridge, C. A., Murfet, I. C., Kerhoas, L., Sotta, B., Miginiac, E., Rameau, C. (1997): The shoot controls zeatin riboside export from pea roots. Evidence from the branching mutant rms4. - The Plant Journal 11(2): 339-345.

[6] Cai, H., Lu, Y., Xie, W., Zhu, T., Lian, X. (2012): Transcriptome response to nitrogen starvation in rice. - Journal of Biosciences 37(4): 731-747.

[7] Cañas, R. A., Quilleré, I., Christ, A., Hirel, B. (2009): Nitrogen metabolism in the developing ear of maize (Zea mays): analysis of two lines contrasting in their mode of nitrogen management. - New Phytologist 184(2): 340-352.

[8] Causin, H. F., Barneix, A. J. (1993): Regulation of $\mathrm{NH}_{4}{ }^{+}$uptake in wheat plants: Effect of root ammonium concentration and amino acids. - Plant and Soil 151(2): 211-218.

[9] Chandna, P., Khurana, M. L., Ladha, J. K., Punia, M., Mehla, R. S., Gupta, R. (2011): Spatial and seasonal distribution of nitrate- $\mathrm{N}$ in groundwater beneath the rice-wheat cropping system of India: a geospatial analysis. - Environmental Monitoring and Assessment 178(1-4): 545-562.

[10] Chin, T. Y., Beevers, L. (1970): Changes in endogenous growth regulators in nasturtium leaves during senescence. - Planta 92(2): 178-188.

[11] Chun, L., Chen, F., Zhang, F., Mi, G. (2005a): Root growth, nitrogen uptake and yield formation of hybrid maize with different $\mathrm{N}$ efficiency. - Plant Nutrition and Fertilizer Science 11(5): 615-619.

[12] Chun, L., Mi, G., Li, J., Chen, F., Zhang, F. (2005b): Genetic analysis of maize root characteristics in response to low nitrogen stress. - Plant and Soil 276(1-2): 369-382.

[13] Gao, K., Chen, F., Yuan, L., Zhang, F., Mi, G. (2015): A comprehensive analysis of root morphological changes and nitrogen allocation in maize in response to low nitrogen stress. - Plant, Cell \& Environment 38(4): 740-750.

[14] Garnett, T., Conn, V., Kaiser, B. N., (2009): Root based approaches to improving nitrogen use efficiency in plants. - Plant, Cell \& Environment 32(9): 1272-1283. 
[15] Geilfus, C. M., Zörb, C., Neuhaus, C., Hansen, T., Lüthen, H., Mühling, K. H. (2011): Differential transcript expression of wall-loosening candidates in leaves of maize cultivars differing in salt resistance. - Journal of Plant Growth Regulation 30(4): 387395.

[16] Glass, A. D. (2003): Nitrogen use efficiency of crop plants: physiological constraints upon nitrogen absorption. - Critical Reviews in Plant Sciences 22(5): 453-470.

[17] Goron, T. L., Bhosekar, V. K., Shearer, C. R., Watts, S., Raizada, M. N. (2015): Whole plant acclimation responses by finger millet to low nitrogen stress. - Frontiers in Plant Science 6: 652.

[18] Guo, T., Xuan, H., Yang, Y., Wang, L., Wei, L., Wang, Y., Kang, G. (2014): Transcription analysis of genes encoding the wheat root transporter NRT1 and NRT2 families during nitrogen starvation. - Journal of Plant Growth Regulation 33(4): 837-848.

[19] Guo, Y., Mi, G., Chen, F., Zhang, F. (2005): Effect of $\mathrm{NO}_{3}$ supply on lateral root growth in maize plants. - Journal of Plant Physiology and Molecular Biology 31: 90-96.

[20] Han, J., Wang, L., Zheng, H., Pan, X., Li, H., Chen, F., Li, X. (2015): ZD958 is a lownitrogen-efficient maize hybrid at the seedling stage among five maize and two teosinte lines. - Planta 242: 935-949.

[21] Hirel, B., Le Gouis, J., Ney, B., Gallais, A. (2007): The challenge of improving nitrogen use efficiency in crop plants: towards a more central role for genetic variability and quantitative genetics within integrated approaches. - Journal of Experimental Botany 58(9): 2369-2387.

[22] Jiang, K., Feldman, L. J. (2002): Root meristem establishment and maintenance: the role of auxin. - Journal of Plant Growth Regulation 21(4): 432-440.

[23] Jones, B., Gunnerås, S. A., Petersson, S. V., Tarkowski, P., Graham, N., May, S., Dolezal, K., Sandberg, G., Ljung, K. (2010): Cytokinin regulation of auxin synthesis in Arabidopsis involves a homeostatic feedback loop regulated via auxin and cytokinin signal transduction. - The Plant Cell 22: 2956-2969.

[24] Ju, X., Liu, X., Zhang, F., Roelcke, M. (2004): Nitrogen fertilization, soil nitrate accumulation, and policy recommendations in several agricultural regions of China. AMBIO: A Journal of the Human Environment 33(6): 300-305.

[25] Li, Y., He, N., Hou, J., Xu, L., Liu, C., Zhang, J., Wang, Q., Zhang, X., Wu, X. (2018): Factors influencing leaf chlorophyll content in natural forests at the biome scale. Frontiers in Ecology and Evolution 6: 64.

[26] Liu, X., Zhang, Y., Han, W., Tang, A., Shen, J., Cui, Z., Vitousek, P., Erisman, J. W., Goulding, K., Christie, P., Fangmeier, A. (2013): Enhanced nitrogen deposition over China. - Nature 494(7438): 459.

[27] Long, S. P., Ainsworth, E. A., Rogers, A., Ort, D. R. (2004): Rising atmospheric carbon dioxide: plants FACE the future. - Annual Review of Plant Biology 55: 591-628.

[28] Marsch-Martinez, N., de Folter, S. (2016): Hormonal control of the development of the gynoecium. - Current Opinion in Plant Biology 29: 104-114.

[29] Marschner, H., (1995): Mineral Nutrition of Higher Plants. 2nd Ed. - Academic Press, San Diego, CA.

[30] Miller and Cramer, A. J., Cramer, M. D. (2005): Root Nitrogen Acquisition and Assimilation. - In: Lambers, H., Colmer, T. D. (eds.) Root Physiology: From Gene to Function. Springer, Dordrecht, pp. 1-36.

[31] Muchow, R. C., Sinclair, T. R. (1994): Nitrogen response of leaf photosynthesis and canopy radiation use efficiency in field-grown maize and sorghum. - Crop Science 34(3): 721-727.

[32] Nadeem, F., Ahmad, Z., Wang, R., Han, J., Shen, Q., Chang, F., Diao, X., Zhang, F., Li, X. (2018): Foxtail Millet [Setaria italica (L.) Beauv.] Grown under low nitrogen shows a smaller root system, enhanced biomass accumulation, and nitrate transporter expression. - Frontiers in Plant Science 9: 205. 
[33] Nasholm, T., Persson, J. (2001): Plant acquisition of organic nitrogen in boreal forests. Physiologia Plantarum 111(4): 419-426.

[34] Palta, J. A., Chen, X., Milroy, S. P., Rebetzke, G. J., Dreccer, M. F., Watt, M. (2011): Large root systems: are they useful in adapting wheat to dry environments. - Functional Plant Biology 38(5): 347-354.

[35] Puangfoo - Lonhienne, C., Lonhienne, T. G., Rentsch, D., Robinson, N., Christie, M., Webb, R. I., Gamage, H. K., Carroll, B. J., Schenk, P. M., Schmidt, S. (2008): Plants can use protein as a nitrogen source without assistance from other organisms. - Proceedings of the National Academy of Sciences 105(11): 4524-4529.

[36] Peng, Y., Niu, J., Peng, Z., Zhang, F., Li, C. (2010): Shoot growth potential drives N uptake in maize plants and correlates with root growth in the soil. - Field Crops Research 115(1): 85-93.

[37] Postgate, J. (1998): Nitrogen Fixation. 3rd Ed. - Cambridge University Press, Cambridge, NY.

[38] Pratelli, R., Pilot, G. (2014): Regulation of amino acid metabolic enzymes and transporters in plants. - Journal of Experimental Botany 65(19): 5535-5556.

[39] Rawat, S. K., Singh, R. K., Singh, R. P. (2012): Remediation of nitrite contamination in ground and surface waters using aquatic macrophytes. - Journal of Environmental Biology 33(1): 51.

[40] Reed, J. W., (2001): Roles and activities of Aux/IAA proteins in Arabidopsis. - Trends in Plant Science 6(9): 420-425.

[41] Robertson, G. P., Vitousek, P. M. (2009): Nitrogen in agriculture: balancing the cost of an essential resource. - Annual Review of Environment and Resources 34: 97-125.

[42] Rodgers, C. O.; Barneix, A. J. (1989): The effect of N-deprivation on nitrate uptake and growth rate of two wheat cultivars selected for different fertility levels. - Plant Physiology and Biochemistry 27: 387-392.

[43] Rosen, H. (1957): A modified ninhydrin colorimetric analysis for amino acids. Archives of Biochemistry and Biophysics 67(1): 10-15.

[44] Sakakibara, H. (2006): Cytokinins: activity, biosynthesis, and translocation. - Annual Review of Plant Biology 57: 431-449.

[45] Santner, A., Calderon-Villalobos, L. I. A., Estelle, M. (2009): Plant hormones are versatile chemical regulators of plant growth. - Nature Chemical Biology 5(5): 301.

[46] Seebauer, J. R., Moose, S. P., Fabbri, B. J., Crossland, L. D., Below, F. E. (2004): Amino acid metabolism in maize earshoots. Implications for assimilate preconditioning and nitrogen signaling. - Plant Physiology 136(4): 4326-4334.

[47] Tian, Q., Chen, F., Liu, J., Zhang, F., Mi, G. (2008): Inhibition of maize root growth by high nitrate supply is correlated with reduced IAA levels in roots. - Journal of Plant Physiology 165(9): 942-951.

[48] Tilman, D., Balzer, C., Hill, J., Befort, B. L. (2011): Global food demand and the sustainable intensification of agriculture. - Proceedings of the National Academy of Sciences 108(50): 20260-20264.

[49] Wang, L., Mou, P. P., Huang, J., Wang, J. (2007): Spatial heterogeneity of soil nitrogen in a subtropical forest in China. - Plant and Soil 295(1-2): 137-150.

[50] Wang, Y., Mi, G., Chen, F., Zhang, F. (2003): Genotypic differences in nitrogen uptake by maize inbred lines its relation to root morphology. - Acta Ecologica Sinica 23(2): 297302.

[51] Wang, Y., Mi, G., Chen, F., Zhang, J., Zhang, F. (2005): Response of root morphology to nitrate supply and its contribution to nitrogen accumulation in maize. - Journal of Plant Nutrition 27(12): 2189-2202.

[52] Wang, Y. Y., Hsu, P. K., Tsay, Y. F. (2012): Uptake, allocation and signaling of nitrate. Trends in Plant Science 17(8): 458-467. 
[53] Weiler, E. W., Jourdan, P. S., Conrad, W. (1981): Levels of indole-3-acetic acid in intact and decapitated coleoptiles as determined by a specific and highly sensitive solid-phase enzyme immunoassay. - Planta 153(6): 561-571.

[54] Wellburn, A. R., Lichtenthaler, H. (1984): Formulae and Program to Determine Total Carotenoids and Chlorophylls $\mathrm{a}$ and $\mathrm{b}$ of Leaf Extracts in Different Solvents. - In: Sybesma, C. (ed.) Advances in Photosynthesis Research. Springer, Dordrecht, pp. 9-12.

[55] Willmer, C. M., Rutter, J. C., Meidner, H. (1983): Potassium involvement in stomatal movements of Paphiopedilum. - Journal of Experimental Botany 34(5): 507-513.

[56] Wolters, H., Jürgens, G. (2009): Survival of the flexible: hormonal growth control and adaptation in plant development. - Nature Reviews Genetics 10(5): 305.

[57] Xu, G., Fan, X., Miller, A. J. (2012): Plant nitrogen assimilation and use efficiency. Annual Review of Plant Biology 63: 153-182.

[58] Yamaguchi, S. (2008): Gibberellin metabolism and its regulation. - Annual Review of Plant Biology 59: 225-251.

[59] Yang, H., Stierhof, Y. D., Ludewig, U. (2015): The putative Cationic Amino Acid Transporter 9 is targeted to vesicles and may be involved in plant amino acid homeostasis. - Frontiers in Plant Science 6: 212.

[60] Yuan, L., Loqué, D., Kojima, S., Rauch, S., Ishiyama, K., Inoue, E., Takahashi, H., von Wirén, N. (2007): The organization of high-affinity ammonium uptake in Arabidopsis roots depends on the spatial arrangement and biochemical properties of AMT1-type transporters. - The Plant Cell 19(8): 2636-2652.

[61] Zhao, D., Reddy, K. R., Kakani, V. G., Read, J. J., Carter, G. A. (2003): Corn (Zea mays L.) growth, leaf pigment concentration, photosynthesis and leaf hyperspectral reflectance properties as affected by nitrogen supply. - Plant and Soil 257(1): 205-218.

[62] Zhao, D., Reddy, K. R., Kakani, V. G., Reddy, V. R. (2005): Nitrogen deficiency effects on plant growth, leaf photosynthesis, and hyperspectral reflectance properties of sorghum. - European Journal of Agronomy 22(4): 391-403.

[63] Zhu, Z. L., Chen, D. L. (2002): Nitrogen fertilizer use in China-Contributions to food production, impacts on the environment and best management strategies. - Nutrient Cycling in Agroecosystems 63(2-3): 117-127. 


\section{APPENDIX}

Table A1. Percentage changes in the shoot height and leaf area of oat

\begin{tabular}{|c|c|c|c|c|c|c|c|c|}
\hline \multirow{2}{*}{ Treatment } & \multirow{2}{*}{ Shoot length (cm) } & \multicolumn{3}{|c|}{ Percentage change (\%) } & \multirow{2}{*}{ Leaf area plant ${ }^{-1}\left(\mathrm{~cm}^{-2}\right)$} & \multicolumn{3}{|c|}{ Percentage change (\%) } \\
\hline & & CK to ON & CK to $\mathrm{LN}$ & ON to $L N$ & & CK to $\mathrm{ON}$ & CK to $\mathrm{LN}$ & ON to $L N$ \\
\hline $\begin{array}{l}\text { CK } \\
\text { ON } \\
\text { LN }\end{array}$ & $\begin{array}{c}58.75 \pm 4.11 \mathrm{a} \\
50 \pm 2.58 \mathrm{~b} \\
42.25 \pm 2.63 \mathrm{c}\end{array}$ & -14.89 & -28.09 & -15.5 & $\begin{array}{c}18.3 \pm 1.6 \mathrm{a} \\
15.2 \pm 0.97 \mathrm{~b} \\
8.9 \pm 0.81 \mathrm{c}\end{array}$ & -16.94 & -51.37 & -41.45 \\
\hline
\end{tabular}

Different letters after the values within the same column indicated significant differences $(\mathrm{P}<0.05)$. Values show standard errors $(\mathrm{SE}) \pm$ mean of four replicates. $\mathrm{CK}=100 \%$ chemical $\mathrm{N}, \mathrm{ON}=100 \%$ organic $\mathrm{N}$ and $\mathrm{LN}=\mathrm{Low} \mathrm{N}$. Percentage change $\mathrm{CK}$ to $\mathrm{ON}=[($ value under $\mathrm{ON}-$ Value under $\mathrm{CK}) /$ Value under $\mathrm{CK}] \times 100, \mathrm{CK}$ to $\mathrm{LN}=[($ value under $\mathrm{LN}-\mathrm{Value}$ under $\mathrm{CK}) / \mathrm{Value}$ under $\mathrm{CK}] \times 100, \mathrm{ON}$ to $\mathrm{LN}=$ $[($ value under $\mathrm{LN}-$ Value under $\mathrm{ON}) /$ Value under $\mathrm{ON}] \times 100$

Table A2. Percentage changes in the shoot dry weight, root dry weight and root shoot ratio

\begin{tabular}{|c|c|c|c|c|c|c|c|c|c|c|c|c|}
\hline \multirow{2}{*}{ Treatment } & \multirow{2}{*}{\begin{tabular}{|c|} 
Shoot dry weight \\
(g)
\end{tabular}} & \multicolumn{3}{|c|}{ Percentage change (\%) } & \multirow{2}{*}{$\begin{array}{l}\text { Root dry } \\
\text { weight (g) }\end{array}$} & \multicolumn{3}{|c|}{ Percentage change (\%) } & \multirow{2}{*}{ Root/shoot ratio } & \multicolumn{3}{|c|}{ Percentage change (\%) } \\
\hline & & CK to ON & CK to $\mathrm{LN}$ & ON to $L N$ & & ON to CK & LN to CK & LN to ON & & CK to ON & CK to $\mathrm{LN}$ & ON to $\mathrm{LN}$ \\
\hline CK & $0.91 \pm 0.03 \mathrm{a}$ & & & & $0.23 \pm 0.02 \mathrm{c}$ & & & & $0.252 \pm 0.01 \mathrm{c}$ & & & \\
\hline $\begin{array}{l}\text { ON } \\
\text { LN }\end{array}$ & $\begin{array}{l}0.77 \pm 0.04 b \\
0.49 \pm 0.04 c\end{array}$ & 15.38 & -45.77 & -35.75 & $\begin{array}{l}0.32 \pm 0.02 \mathrm{~b} \\
0.42 \pm 0.02 \mathrm{a}\end{array}$ & 39.13 & 82.61 & 31.25 & $\begin{array}{l}0.41 \pm 0.04 b \\
0.86 \pm 0.06 \mathrm{a}\end{array}$ & 62.7 & $\begin{array}{c}241.27(3.41 \\
\text { fold more) }\end{array}$ & $\begin{array}{l}109.76(2.1 \\
\text { fold more) }\end{array}$ \\
\hline
\end{tabular}

Different letters after the values within the same column indicated significant differences $(\mathrm{P}<0.05)$. Values show standard errors ( $\mathrm{SE}$ ) \pm mean of four replicates. $\mathrm{CK}=100 \%$ chemical $\mathrm{N}$, ON $=100 \%$ organic $\mathrm{N}$ and $\mathrm{LN}=\mathrm{Low} \mathrm{N}$. Percentage change $\mathrm{CK}$ to $\mathrm{ON}=[($ value under $\mathrm{ON}-$ Value under $\mathrm{CK}) /$ Value under $\mathrm{CK}] \times 100, \mathrm{CK}$ to $\mathrm{LN}=[($ value under $\mathrm{LN}-\mathrm{Value}$ under $\mathrm{CK}) / \mathrm{Value}$ under $\mathrm{CK}] \times 100, \mathrm{ON}$ to $\mathrm{LN}=$

$[($ value under $\mathrm{LN}-$ Value under ON $) /$ Value under ON $] \times 100$

Table A3. Percentage changes in the $N$ concentration $C / N$ ratio, $N$ utilization efficiency in the shoot and root of oat

\begin{tabular}{|c|c|c|c|c|c|c|c|c|c|c|c|c|c|}
\hline & \multirow{2}{*}{ Treatment } & \multirow{2}{*}{$\begin{array}{c}\mathrm{N} \text { concentration } \\
\left(\mathrm{g} \mathrm{kg}^{-1}\right)\end{array}$} & \multicolumn{3}{|c|}{ Percentage change (\%) } & \multirow{2}{*}{$\mathrm{C} / \mathrm{N}$ ratio } & \multicolumn{3}{|c|}{ Percentage change (\%) } & \multirow{2}{*}{ NUtE } & \multicolumn{3}{|c|}{ Percentage change (\%) } \\
\hline & & & CK to ON & CK to LN & ON to LN & & CK to ON & CK to $\mathrm{LN}$ & ON to $\mathrm{LN}$ & & CK to ON & CK to $\mathrm{LN}$ & ON to $L N$ \\
\hline Shoot & $\begin{array}{l}\text { CK } \\
\text { ON } \\
\text { LN }\end{array}$ & $\begin{array}{c}46.2 \pm 3.23 a \\
31.23 \pm 2.09 b \\
22.17 \pm 2.64 c\end{array}$ & -32.4 & -52.01 & -29.01 & $\begin{array}{c}8.76 \pm 1.12 \mathrm{c} \\
13.32 \pm 1.04 \mathrm{~b} \\
18.52 \pm 2.64 \mathrm{a}\end{array}$ & 52.05 & 111.42 & 39.04 & $\begin{array}{l}21.65 \pm 1.19 \mathrm{c} \\
32.02 \pm 1.16 \mathrm{~b} \\
45.11 \pm 3.19 \mathrm{a}\end{array}$ & 47.9 & 108.36 & 40.88 \\
\hline Root & $\begin{array}{l}\text { CK } \\
\text { ON } \\
\text { LN }\end{array}$ & $\begin{array}{c}33.33 \pm 2.12 \mathrm{a} \\
25.2 \pm 2.19 \mathrm{~b} \\
11.87 \pm 1.32 \mathrm{c}\end{array}$ & -24.39 & -64.39 & -52.9 & $\begin{array}{l}12.08 \pm 1.12 \mathrm{c} \\
16.97 \pm 1.57 \mathrm{~b} \\
35.43 \pm 2.78 \mathrm{a}\end{array}$ & 40.48 & 193.23 & 108.78 & $\begin{array}{c}30 \pm 2.19 \mathrm{c} \\
39.68 \pm 5.97 \mathrm{~b} \\
84.27 \pm 3.82 \mathrm{a}\end{array}$ & 32.27 & 180.9 & 112.37 \\
\hline
\end{tabular}

Different letters after the values within the same column indicated significant differences $(\mathrm{P}<0.05)$. Values show standard errors ( $\mathrm{SE}$ ) \pm mean of four replicates. $\mathrm{CK}=100 \%$ chemical $\mathrm{N}$, ON $=100 \%$ organic $\mathrm{N}$ and $\mathrm{LN}=\mathrm{Low}$. Percentage change $\mathrm{CK}$ to $\mathrm{ON}=[($ value under $\mathrm{ON}-$ Value under $\mathrm{CK}) /$ Value under $\mathrm{CK}] \times 100, \mathrm{CK}$ to $\mathrm{LN}=[($ value under $\mathrm{LN}-\mathrm{Value}$ under $\mathrm{CK}) / \mathrm{Value}$ under $\mathrm{CK}] \times 100, \mathrm{ON}$ to $\mathrm{LN}=$ $[($ value under $\mathrm{LN}-$ Value under ON $) /$ Value under ON $] \times 100$ 
Table A4. Percentage changes in the crown root number, lateral root number and lateral root density under different treatment

\begin{tabular}{|c|c|c|c|c|c|c|c|c|c|c|c|c|}
\hline \multirow{2}{*}{ Treatment } & \multirow{2}{*}{$\begin{array}{c}\text { Crown root } \\
\text { number }\end{array}$} & \multicolumn{3}{|c|}{ Percentage change $(\%)$} & \multirow{2}{*}{$\begin{array}{c}\text { Lateral root } \\
\text { number }\end{array}$} & \multicolumn{3}{|c|}{ Percentage change $(\%)$} & \multirow{2}{*}{$\begin{array}{l}\text { Lateral root } \\
\text { density }\end{array}$} & \multicolumn{3}{|c|}{ Percentage change (\%) } \\
\hline & & CK to $\mathrm{ON}$ & CK to $\mathrm{LN}$ & ON to $\mathrm{LN}$ & & ON to $\mathrm{CK}$ & LN to CK & LN to $O N$ & & CK to $\mathrm{ON}$ & CK to $\mathrm{LN}$ & ON to $\mathbf{L N}$ \\
\hline CK & $7.5 \pm 0.87 b$ & & & & $1736.17 \pm 145.2 \mathrm{c}$ & & & & $7.8 \pm 0.98 \mathrm{~b}$ & & & \\
\hline ON & $10.5 \pm 1.08 \mathrm{~b}$ & 40 & 96.67 & 40.47 & $2000.4 \pm 123.3 \mathrm{~b}$ & 15.22 & 34.1 & 16.39 & $10.6 \pm 1.76 \mathrm{~b}$ & 35.9 & 128.21 & 67.92 \\
\hline $\mathbf{L N}$ & $14.75 \pm 2.2 \mathrm{a}$ & & & & $2328.17 \pm 155.8 \mathrm{a}$ & & & & $17.8 \pm 2.01 \mathrm{a}$ & & & \\
\hline
\end{tabular}

Different letters after the values within the same column indicated significant differences $(\mathrm{P}<0.05)$. Values show standard errors (SE) \pm mean of four replicates. $\mathrm{CK}=100 \%$ chemical $\mathrm{N}$, ON $=100 \%$ organic $\mathrm{N}$ and $\mathrm{LN}=\mathrm{Low} \mathrm{N}$. Percentage change $\mathrm{CK}$ to $\mathrm{ON}=[($ value under $\mathrm{ON}-$ Value under $\mathrm{CK}) /$ Value under $\mathrm{CK}] \times 100, \mathrm{CK}$ to $\mathrm{LN}=[($ value under $\mathrm{LN}-\mathrm{Value}$ under $\mathrm{CK}) / \mathrm{Value}$ under $\mathrm{CK}] \times 100, \mathrm{ON}$ to $\mathrm{LN}=$ [(value under LN - Value under ON)/Value under ON] $\times 100$

Table A5. Percentage changes in the crown root length, lateral root length and total root length under different treatment

\begin{tabular}{|c|c|c|c|c|c|c|c|c|c|c|c|}
\hline \multirow{2}{*}{$\begin{array}{c}\text { Crown root length } \\
\text { (cm) }\end{array}$} & \multicolumn{3}{|c|}{ Percentage change $(\%)$} & \multirow{2}{*}{$\begin{array}{l}\text { Lateral root length } \\
\text { (cm) }\end{array}$} & \multicolumn{3}{|c|}{ Percentage change (\%) } & \multirow{2}{*}{$\begin{array}{c}\text { Total root length } \\
(\mathrm{cm})\end{array}$} & \multicolumn{3}{|c|}{ Percentage change (\%) } \\
\hline & CK to ON & CK to LN & ON to $\mathrm{LN}$ & & ON to $\mathrm{CK}$ & LN to CK & $\mathrm{LN}$ to $\mathrm{ON}$ & & CK to ON & CK to $\mathrm{LN}$ & ON to $\mathrm{LN}$ \\
\hline $\begin{array}{c}143.34 \pm 10.56 \mathrm{~b} \\
176.23 \pm 13.98 \mathrm{~b} \\
310 \pm 17.76 \mathrm{a}\end{array}$ & 22.95 & 116.27 & 75.91 & $\begin{array}{c}1288.16 \pm 82.2 \mathrm{c} \\
1667.22 \pm 102.1 \mathrm{~b} \\
2725.3 \pm 178.3 \mathrm{a}\end{array}$ & 29.43 & 111.57 & 63.46 & $\begin{array}{c}1431.5 \pm 97.36 \mathrm{c} \\
1843.45 \pm 131.23 \mathrm{~b} \\
3035.33 \pm 198.3 \mathrm{a}\end{array}$ & 28.78 & 112.3 & 64.65 \\
\hline
\end{tabular}

Different letters after the values within the same column indicated significant differences $(\mathrm{P}<0.05)$. Values show standard errors $(\mathrm{SE}) \pm$ mean of four replicates. $\mathrm{CK}=100 \%$ chemical $\mathrm{N}, \mathrm{ON}=100 \%$ organic $\mathrm{N}$ and $\mathrm{LN}=\mathrm{Low} \mathrm{N}$. Percentage change $\mathrm{CK}$ to $\mathrm{ON}=[($ value under $\mathrm{ON}-$ Value under $\mathrm{CK}) /$ Value under $\mathrm{CK}] \times 100, \mathrm{CK}$ to $\mathrm{LN}=[($ value under $\mathrm{LN}-\mathrm{Value}$ under $\mathrm{CK}) / \mathrm{Value}$ under $\mathrm{CK}] \times 100, \mathrm{ON}$ to $\mathrm{LN}=$

$[($ value under $\mathrm{LN}-$ Value under ON)/Value under ON $] \times 100$

Table A6. Percentage changes in the chlorophyll a, chlorophyll $b$ and carotenoid in oat leaf under different treatment

\begin{tabular}{|c|c|c|c|c|c|c|c|c|c|c|c|c|}
\hline \multirow{2}{*}{ Treatment } & \multirow{2}{*}{$\begin{array}{c}\text { Chlorophyll a } \\
\text { content/mg g g-1 } \\
\text { FW }\end{array}$} & \multicolumn{3}{|c|}{ Percentage change $(\%)$} & \multirow{2}{*}{$\begin{array}{c}\text { Chlorophyll b } \\
\text { content/mg g }{ }^{-1} \\
\text { FW }\end{array}$} & \multicolumn{3}{|c|}{ Percentage change $(\%)$} & \multirow{2}{*}{$\begin{array}{c}\text { Carotenoid } \\
\text { content/mg g-1 } \\
\text { FW }\end{array}$} & \multicolumn{3}{|c|}{ Percentage change $(\%)$} \\
\hline & & CK to ON & CK to $\mathrm{LN}$ & ON to $\mathrm{LN}$ & & ON to $\mathrm{CK}$ & LN to CK & LN to ON & & CK to ON & CK to LN & ON to $L N$ \\
\hline CK & $3.44 \pm 0.09 \mathrm{a}$ & & & & $1.47 \pm 0.12 \mathrm{a}$ & & & & $0.7 \pm 0.02 \mathrm{a}$ & & & \\
\hline ON & $3.01 \pm 0.07 \mathrm{~b}$ & -12.5 & -20.93 & -9.63 & $1.23 \pm 0.08 b$ & -16.36 & -44.9 & -34.15 & $0.61 \pm 0.02 b$ & -12.86 & -30 & -19.67 \\
\hline $\mathbf{L N}$ & $2.72 \pm 0.05 \mathrm{c}$ & & & & $0.81 \pm 0.06 \mathrm{c}$ & & & & $0.49 \pm 0.01 \mathrm{c}$ & & & \\
\hline
\end{tabular}

Different letters after the values within the same column indicated significant differences $(\mathrm{P}<0.05)$. Values show standard errors (SE) \pm mean of four replicates. $\mathrm{CK}=100 \%$ chemical $\mathrm{N}, \mathrm{ON}=100 \%$ organic $\mathrm{N}$ and $\mathrm{LN}=\mathrm{Low}$. Percentage change CK to ON $=[($ value under ON - Value under $\mathrm{CK}) / \mathrm{Value}$ under $\mathrm{CK}] \times 100, \mathrm{CK}$ to $\mathrm{LN}=[($ value under $\mathrm{LN}-\mathrm{Value}$ under $\mathrm{CK}) / \mathrm{Value}$ under $\mathrm{CK}] \times 100, \mathrm{ON}$ to $\mathrm{LN}=$ $[($ value under $\mathrm{LN}-$ Value under ON)/Value under $\mathrm{ON}] \times 100$ 
Table A7. Percentage changes in the concentration of free amino acids, total soluble protein and soluble sugars in the shoot and root of oat

\begin{tabular}{|c|c|c|c|c|c|c|c|c|c|c|c|c|c|}
\hline & \multirow[b]{2}{*}{ Treatment } & \multirow[b]{2}{*}{$\begin{array}{l}\text { Free amino acids } \\
\quad\left(\mathrm{mg} \mathrm{g}^{-1} \mathrm{FW}\right)\end{array}$} & \multicolumn{3}{|c|}{ Percentage change (\%) } & \multirow{2}{*}{$\begin{array}{l}\text { Total soluble } \\
\text { protein } \\
\left(\mathbf{m g ~ g}^{-1} \mathbf{F W}\right)\end{array}$} & \multicolumn{3}{|c|}{ Percentage change (\%) } & \multirow[b]{2}{*}{$\begin{array}{l}\text { Total soluble sugar } \\
\quad\left(\mathrm{mg} \mathrm{g}^{-1} \text { FW }\right)\end{array}$} & \multicolumn{3}{|c|}{ Percentage change (\%) } \\
\hline & & & $\begin{array}{c}\text { CK to } \\
\text { ON }\end{array}$ & CK to LN & ON to $\mathbf{L N}$ & & $\begin{array}{c}\text { CK to } \\
\text { ON }\end{array}$ & CK to LN & ON to $\mathrm{LN}$ & & CK to ON & CK to $\mathrm{LN}$ & ON to $\mathrm{LN}$ \\
\hline Shoot & $\begin{array}{l}\text { CK } \\
\text { ON } \\
\text { LN }\end{array}$ & $\begin{array}{l}600.29 \pm 47.4 a \\
542.46 \pm 26.3 a \\
439.56 \pm 37.3 b\end{array}$ & -9.6 & -26.78 & -18.97 & $\begin{array}{l}7.9 \pm 0.99 \mathrm{a} \\
4.1 \pm 0.82 \mathrm{~b} \\
2.1 \pm 0.38 \mathrm{~b}\end{array}$ & -48.1 & -73.42 & -48.78 & $\begin{array}{l}9.7 \pm 0.98 \mathrm{a} \\
6.2 \pm 0 . .83 \mathrm{~b} \\
4.1 \pm 0.33 \mathrm{~b} \\
\end{array}$ & -36.08 & -57.73 & -33.87 \\
\hline Root & $\begin{array}{l}\text { CK } \\
\text { ON } \\
\text { LN }\end{array}$ & $\begin{array}{l}592.04 \pm 49.25 \mathrm{a} \\
510.14 \pm 45.96 \mathrm{a} \\
378.71 \pm 32.66 \mathrm{~b}\end{array}$ & -13.83 & -36.03 & -25.76 & $\begin{array}{c}1.42 \pm 0.18 \mathrm{~b} \\
2.13 \pm 0.2 \mathrm{~b} \\
4.19 \pm 0.32 \mathrm{a}\end{array}$ & 50 & 195 & 99.71 & $\begin{array}{c}0.62 \pm 0.12 \mathrm{~b} \\
0.89 \pm 0 . .23 \mathrm{~b} \\
1.61 \pm 0.31 \mathrm{a}\end{array}$ & 43.54 & 159.68 & 80.9 \\
\hline
\end{tabular}

Different letters after the values within the same column indicated significant differences $(\mathrm{P}<0.05)$. Values show Standard errors (SE) \pm mean of four replicates. CK $=100 \%$ chemical $\mathrm{N}$, ON $=100 \%$ organic $\mathrm{N}$ and $\mathrm{LN}=$ Low $\mathrm{N}$. Percentage change $\mathrm{CK}$ to $\mathrm{ON}=[($ value under ON - Value under CK)/Value under $\mathrm{CK}] * 100, \mathrm{CK}$ to $\mathrm{LN}=[($ value under $\mathrm{LN}-\mathrm{Value}$ under $\mathrm{CK}) / \mathrm{Value}$ under CK $] * 100, \mathrm{ON}$ to $\mathrm{LN}=[($ value under $\mathrm{LN}-$ Value under $\mathrm{ON}) /$ Value under $\mathrm{ON}] * 100$

Table A8. Correlation coefficient between root morphological traits and nutrient concentration in oat plant root

\begin{tabular}{|c|c|c|c|c|c|c|c|}
\hline Nutrient & Crown root number & Seminal root number & Seminal root density & Crown root length & Lateral root length & Total root length & Average root diameter \\
\hline $\mathrm{P}$ & $0.656^{*}$ & 0.54 & $0.619^{*}$ & $0.579 *$ & $0.662 *$ & $0.651^{*}$ & 0.56 \\
\hline K & $-0.713^{* *}$ & $-0.785^{* *}$ & $-0.718 * *$ & $-0.731 * *$ & $-0.749^{* *}$ & $-0.759 * *$ & $-0.853^{* *}$ \\
\hline $\mathrm{Ca}$ & -0.12 & 0.05 & -0.15 & -0.22 & -0.16 & -0.17 & 0.001 \\
\hline $\mathrm{Mg}$ & $0.907 * *$ & $0.877^{* *}$ & $0.902^{* *}$ & $0.956^{* *}$ & $0.967^{* *}$ & $0.977^{* *}$ & $0.963^{* *}$ \\
\hline $\mathrm{Fe}$ & -0.017 & 0.14 & -0.04 & -0.13 & -0.06 & -0.07 & 0.10 \\
\hline $\mathrm{Cu}$ & $0.925 * *$ & $0.868^{* *}$ & $0.922^{* *}$ & $0.958^{* *}$ & $0.976^{* *}$ & $0.983^{* *}$ & $0.953^{* *}$ \\
\hline $\mathrm{Mn}$ & $0.764 * *$ & $0.803^{* *}$ & $0.759^{* *}$ & $0.776^{* *}$ & $0.804 * *$ & $0.814^{* *}$ & $0.905^{* *}$ \\
\hline $\mathrm{Zn}$ & $0.808^{* *}$ & $0.706^{*}$ & $0.819^{* *}$ & $0.918^{* *}$ & $0.886^{* *}$ & $0.904 * *$ & $0.897^{* *}$ \\
\hline B & $0.925 * *$ & $0.877^{* *}$ & $0.916^{* *}$ & $0.938^{* *}$ & $0.969^{* *}$ & $0.973^{* *}$ & $0.941^{* *}$ \\
\hline S & $-0.817^{* *}$ & $-0.773 * *$ & $-0.822 * *$ & $0-.886^{* *}$ & $-0.891 * *$ & $-0.907 * *$ & $-0.942^{* *}$ \\
\hline $\mathrm{Na}$ & $0.878 * *$ & $0.899^{* *}$ & $0.866 * *$ & $0.927 * *$ & $0.941^{* *}$ & $0.954 * *$ & $0.954 * *$ \\
\hline
\end{tabular}

Tissue samples were taken just prior to harvesting. Significant decreases or increases were indicted by ' ${ }^{*}$ 'or ${ }^{* * *}$. $* \mathrm{P}<0.05 ; * * \mathrm{P}<0.01$ 